ORNL- -6445

DE88 007859

\title{
ORNL LONG-RANGE ENVIRONMENTAL AND WASTT MANAGEMENT PLAN
}

\begin{tabular}{|c|c|}
\hline L. D. Bates & L. E McNeese \\
\hline J. B. Berry & T. E. Myrick \\
\hline G. E. Butterworth & R. E. Pudelek \\
\hline S. P. du Mont III & P. S. Rohwer \\
\hline C. A. Easterday & T. F. Scanlan \\
\hline A. H. Geisler & L. E. Stratton \\
\hline L. G. Hill & J. R. Trabalka \\
\hline C. M. Kendrick & E. L. Youngblood \\
\hline
\end{tabular}

December 1987

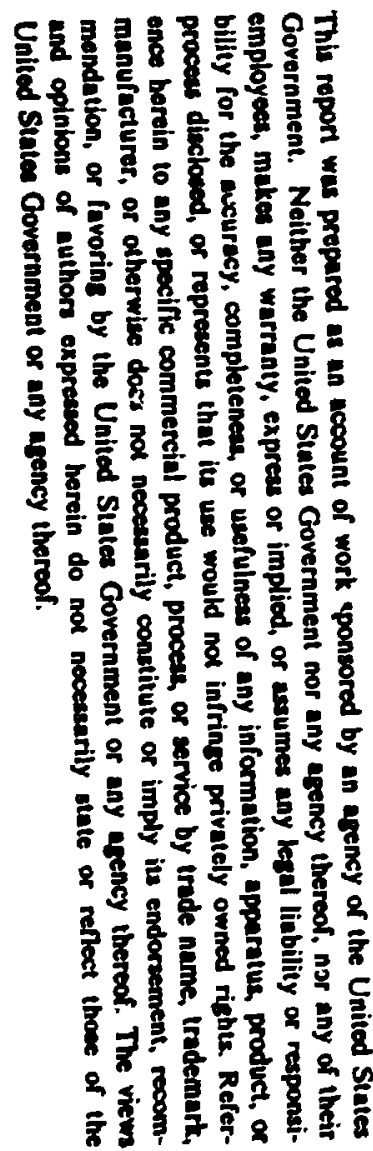

Prepared oy the

OAK RIDGE NATIONAL LABORATORY

Oak Ridge, Tennessee 37831

operated by

MARTIN MARIETTA ENERGY SYSTEMS, INC.

for the

U.S. DEPARTMENT OF ENERGY

under Contract No. DE-AC05-84OR21400

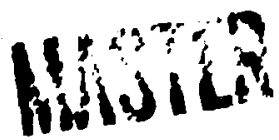


ORNL LONG-RANGE ENVIRONMISNTAL AND WASTE MANAGEMIENT PLAN

LIST OF FIGURES $\ldots \ldots \ldots \ldots \ldots \ldots \ldots \ldots \ldots \ldots \ldots \ldots \ldots \ldots \ldots \ldots$

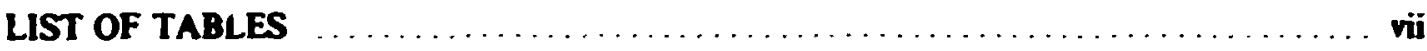

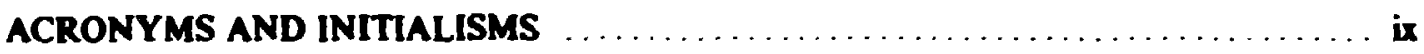

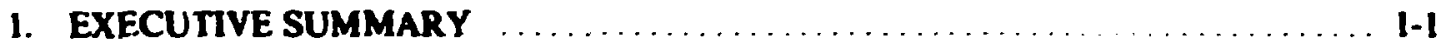

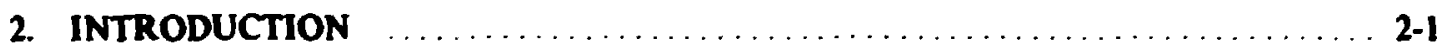

3. COMPREHENSIVE ENVIRONMENTAL MANAGEMENT PROGRAM $\ldots \ldots \ldots$ 3-1

4. AIR POLLUTION CONTROL PROGRAM $\ldots \ldots \ldots \ldots \ldots \ldots \ldots \ldots \ldots$

5. WATER POLLUTION CONTROL PROGRAM $\ldots \ldots \ldots \ldots \ldots \ldots \ldots \ldots \ldots$ s-1

6. SOLID WASTE MANAGEMENT PROGRAM $\ldots \ldots \ldots \ldots \ldots \ldots \ldots \ldots$ 6-1

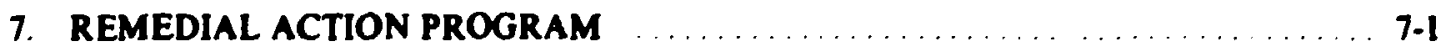

8. ENVIRONMENTAL MONITORING PRÚGRAM $\ldots \ldots \ldots \ldots \ldots \ldots \ldots \ldots$ 8-1

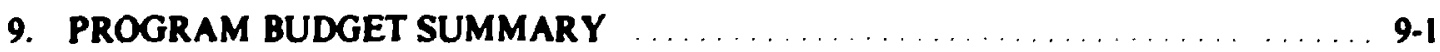




\section{UST OF FIGURIS}

i.1 Logic network for charge-back plan for ORNL waste managemeat

4.I Emission sources at ORNL

4.2 Air pollution control program strategy

4.3 Preliminary schedule for air pollution control program improvements

5.1 Liquid waste categories included in the Water

Pollution Control Program

5.2 Water pollution control program strategy-Part I

5.3 Water pollution control program strategy-Part II

5.4 Schedule for water pollution control program improvements

6.1 General classification of solid waste generated at ORNL.

6.2 Preliminary schedule for solid waste management program improvements

7.1 Remedial Action Program implementation flowchar

7.2 Remedial Action Program implementation schedule.

8.1 Environmental monituring program stracegy

8.2 Preliminary schedule for environmental monitoring program improvements

9.1 ORNL environmental and waste management funding 


\section{LIST OF TABLSS}

I.I Environmental and waste management budget summary $\ldots \ldots \ldots \ldots \ldots \ldots$ 1-8

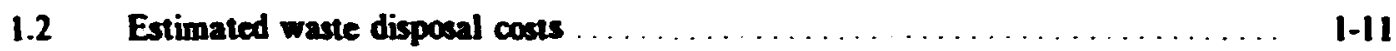

1.3 ORNL Environmental Surveillance Program overhead funding by task ...... I-13

1.4 Funding for routine operations and LLWDDD core program $\ldots \ldots \ldots \ldots \ldots$ 1-14

1.5 ORNL Environmental Program by funding type $\ldots \ldots \ldots \ldots \ldots \ldots \ldots$ I-15

3.1 LLWDDD core program budgets for the period FY 1988 through FY $1994 \ldots$.. 3-3

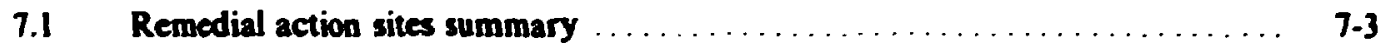

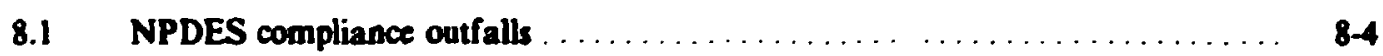

9.I ORNL environmental funding by work-breakdown st ructure $\ldots \ldots \ldots \ldots \ldots \ldots$

9.2 Environmental cross-cut budget authority estimates $\ldots \ldots \ldots \ldots \ldots \ldots \ldots .9 .4$ 


\section{ACRONYMS AND INITIALISMS}

\begin{tabular}{|c|c|}
\hline ACD & Analytical Chemistry Division (ORNL) \\
\hline AcDM & Activity Description Memorandum \\
\hline ADM & Action Description Memeranda \\
\hline ADP & automated data processing \\
\hline ALARA & as low as reasonably achievable \\
\hline BAT & best available technology \\
\hline BMAP & Biological Monitoring and Abatement Program \\
\hline BMP & best management practices \\
\hline CAA & Clean Air Act of 1970 \\
\hline CAT & collection and transfer \\
\hline CERCLA & $\begin{array}{l}\text { Comprehensive Environmental Response, Compensation, and Liability Act } \\
\text { ("Superfund") of } 1980\end{array}$ \\
\hline CFR & Code of Federal Regulations \\
\hline CH-TRU & contact-handled transuranic (wastes) \\
\hline CWA & Clean Water Act of 1977 \\
\hline CWD $\ddot{r}$ & Central Waste Disposal Facility \\
\hline CWSF & Chemical Waste Storage Facility \\
\hline DAS & Data Acquisition System \\
\hline DOE & U.S. Department of Energy \\
\hline EC\&HP & Environmental Compliance and Health Protection Division \\
\hline EMC & Environmental Monitoring and Compliance \\
\hline EMSU & Environmental Monitoring System Upgrade \\
\hline EP & Environmental Projects (Program) \\
\hline EPA & Environmental Protection Agency \\
\hline EPO & Environmental Prutection Officer \\
\hline ERDP & Environmental Review and Documentation Program \\
\hline FPDL & Fission Product Development Laboratory \\
\hline GCD & $\begin{array}{l}\text { greater confinement disposial (an enhanced means for isolating radioactive wastes } \\
\text { on site) }\end{array}$ \\
\hline G.M & Geiger-Müller \\
\hline GPE & general purpose equipment \\
\hline GPP & general plant project \\
\hline HEPA & high-efficiency particulate air (filter) \\
\hline HFIR & High-Flux Isotope Reactor \\
\hline HRE & Homogeneous Reactor Experiment \\
\hline HWMA & Hazardous Waste Management Area \\
\hline HWSF & Hazardous Waste Storage Facility \\
\hline
\end{tabular}


IC impractical to certify (a situation in which it is too dificult to locally certify that a TRI' waste qualifies for acceptance at the WIPP and, therefore, requires special hzodling and/or disposal)

I.AM loc is air inonitor

LERC Laboratory Emergency Response Center (Building 4512)

LIP iine item project

LITR Low-Intensity Test Reactor

LLW liquid low-Jevel (radioactive) waste

I.LW low-level (radioactive) waste

LLW-CAT iLW-collation and transfer

LLWDCD LUW-Level Waste Disposal Development and Demonstration

LTHWSF l ong-Term Hazaidous Waste Storage Facility

M\&S milintenance and surveillance

MAP Mercu.y Assessment Program

MRF Metal Recovery Faciliny

MVST MIeltor Valley Storagi Tanks

N\&CW Nuclear and Chemical Waste (Program)

NAS, NRC National Academy of Sciences, National Research Council

NDA

NDE

nondestructive assay

NEPA National Envi:onmental Policy Act

NESHAP National Emission Standard for Hazaroous Air Pollutants

NPDES National Poliutant Discharge Elimination System

NRC Nuclear Regilatory Commission

NR WTP Nonradiologizal Wastewater Treatment Plant

ORGDP Oak Ridge C.aseous Diffusion Plant

ORNL Oak Ridge National Laboratory

ORO Gak Ridge Operations (DOE)

ORR Oak Ridge Reservation

PA/SI Freliminary Ascessment/Site Investigation

PAM Perimeter Air Monitor

PCB polychlurinated biphenyl

PCBMP PCB Monitoring Plan

PDS project data sheets

PSS project schedule sheets

PW process waste

PWTP Process Wa:te Treatment Plant

QA Gudlity assurance

QC quality cont rol

RAM remote air monitor

RAP Remedial Action Program

R\&D research and development

RCRA Resource Conservation and Recovery Act of 1979

RFA RCRA Faciiity Assessment

RFI/CMS RCR P. Facility Investigation and Corrective Measures Study 


$\begin{array}{ll}\text { RH-TRU } & \text { remote-handled transuranic } \\ \text { RI/FS } & \text { Remedial Investigations/Feasibility Study } \\ \text { RMP } & \text { Radiological Monitoring Plan } \\ \text { SARA } & \text { Superfund Amendments and Reauthorization AC of 1986 } \\ \text { SDWA } & \text { Safe Drinking Water Act } \\ \text { SLB } & \text { shallow land burial } \\ \text { SPCCC } & \text { Spill Prevention Control Countermeasures and Contingency Plans } \\ \text { SWSA } & \text { Solid Waste Storage Area } \\ \text { TBD } & \text { to be determined } \\ \text { TCMP } & \text { Toxicity Control and Monitoring Plan } \\ \text { TDHE } & \text { Tennessee Department of Health and Environment } \\ \text { TEC } & \text { total extimated cost } \\ \text { TRU } & \text { transuranic } \\ \text { TSCA } & \text { Toxic Subatances Control Act of 1976 } \\ \text { TSD } & \text { treatment, storage, and/or disposal } \\ \text { TURF } & \text { Transuranium Recarch Facility } \\ \text { UIC } & \text { Underground Injection Coatrol (TDHE regulations) } \\ \text { WBS } & \text { wort breakdown structure } \\ \text { WHPP } & \text { Waste Handlung Pilot Plant } \\ \text { WIPP } & \text { Waste Isolation Pilot Plant } \\ \text { WMO } & \text { Waste Management Operations (Program) } \\ \text { WMTC } & \text { Waste Management Technology Center } \\ \text { WOC } & \text { White Oak Creek } \\ \text { WOCC } & \text { Waste Operations Control Center } \\ \text { WOL } & \text { White Oak Lake }\end{array}$




\section{EXECUTTVE SUMMARY}

\section{OVERVILW}

This report, the ORNL Lang-Range Environmental and Waste Management Plan, is the annual update in a series begun in fiscal year I985. The primary parpose of this report is to zrovide a thorough and systematic planaing document to reflect the continuing process of site asseasment, strategy development, and planning for the current and long-term control of enviroamental iaswes, waste management practices, and remedial action requirements. The document also provides an extimate of the resources required to implement the current plan. This document is not intended to be a budget document: it is, however, intended to provide guidance to both Martin Marietta Energy Systems, Inc, and the U.S. Deparment of Eaergy (DOE) Managemeat as to the near onder of magnitude of the resources (primarily fonding requirements) and the time frame required to execute the strategy in the present revision of the plan. As with any document of this nature, the near-term (one to three years) part of the plan is a realistic ascessment of the current program and ongoing capital projects and reflects the efforts preceived to be necessary to comply with all current state and federal regulations and DOE orders. It also should be in general agreement with current budget (funding) requests and obligations for these immediate years. Beyond the immediate time frame, the document reflects the strategy and the project and funding estimates as a snapshot at the time of publication. This is intended to be a living document with annual revision to reflect the continuing evolution and development of environmental and waste management processes, characterizations, remedial actions, regulations, and strategies for the establishment and conduct of a comprehensive environmental and waste management program designed to be in compliance with state and federal regulations and guidelines designed to protect human health and the natural environment. In order to maintain uniformity within the environmental and waste management disciplines, the general format of this document has been adopted by Energy Systems' installations for the annual Long-Range Environmental and Waste Management Plans.

\section{BACKGROUND}

Oak Ridge National Laboratory (ORNL) is a multiprogram laboratory operated for the DOE by Martin Marietta Energy Systems, Inc., that conducts research and development (R\&D) activities for other U.S. government agencies, as well as for private industry and institutional organizations. Currently, these research efforts are focused in the areas of (1) magnetic fusion, (2) nuclear fission, (3) biological and environmental basic and applied research, (4) conservation and renewable energy. (5) fossil energy, and (6) basic research in physical sciences. The diversity of these programs and the complement of unique research facilities that support these activities present equally diverse and unique environmental and waste management challenges. Control and treatment of waste streams from the ORNL facilities have been continuing responsibilities of DOE and its managing site contractors since the beginning of Laboratory operations. Effluent monitoring 
has been used to aid waste management operations and to ensure the safety of on-site personnel, the ervironment, and the general public.

Since the start of operations at the ORNL site in 1943, significant changes have occurred in the scope of R\&D efforts and the supporting waste management requirements. While early site development focused on direct support of defense programs during and following World War II, the unique facilities that were extablished formed the nucleus of the multidiscipline research laboratory that now exists. Similarly, waste management requirements have changed over the years. Many of the existing waste management sites and facilities have evolved from what would now be classified as crude disposal practices. Earty waste manafement, which left significant enviroamental concerns unsatisfied, was a product of the limited scientific knowledge of that day and the urgency of the early mission.

Over the past several years, the awareneas of environmental concerns has increased and major environmental legislation has been enacted at both the federal and state levels for controlling exiating and potential sources of pollution. As a result of this changing regulatory environment, recent inspections, andits, and reviews have been carried out . Id revealed the need to accelerate environmental compliance activities, as well as protection of the public and employees, through "as low as reasonably achievable" (ALARA) directives on a more comprehensive basis. Treatment of discharges needs to be upgraded, and results of the earlier disposal practices need to be addressed. Timely action is being taken and will need to continue to bring ORNL into conformance with current and future regulations and guidelines.

\section{COMPREHENSIVE ENVIRONMENTAL MANAGEMENT}

Routine waste management operations are provided through the ORNL Waste Management Operations (WMO) Program as part of its current mission to operate liquid, gaseous, and solid waste management systems. Routine environmental compliance monitoring is provided through the ORNL Environmental Monitoring and Compliance (EMC) Department within the Environmental Compliance and Health Protection Division (EC\&HP). The ORNL Remedial Action Program (RAP) and the ORNL Environmental Projects (EP) Program were established to provide ORNL the capability to comply with existing and future environmental regulations and requirements. These programs address remedial actions and provide the improvements needed for continuec protection of the environment and the healih and safety of on-site workers and the public and for compliance with current and future environmental regulations. These programs have also been improving or Jeveloping waste collection, treatment, storage, and disposal capabilities for all ORNL-generated waste and effluents.

Since these organizational elements have been in place. activities have focused on several key areas with the objective of eatablishing a sound basis for proceeding with the significant long-term commitments that will be required to give ORNL the capability for achieving and maintaining environmental compliance. Some key areas that have been addressed in this initial period include

- establishment of a program management organization and structure;

- assessment of near-term environmental compliance status, resulting in the initiation of a number of activities for attaining compliance in specific areas;

- initiation of strategy development and long-range planning in the major program areas: 
- management of specific facility upgrade and site characterization and assessment tasks; and

- establishment of a working relationship among the staffs of Martin Marietta Energy Systems, DOE, the Tennessee Department of Health and Environment (TDHE), and the U.S. Environmental Protection Agency (EPA).

\section{STATUS OF PLANNING}

This ORNL Long-Range Environmental and Waste Management Plan summarizes the overall environmental and waste management strategy that has been developed to date. The planning activities to be continued over the next one to two years will be critical in defining the scope of work necessary to provide ORNL with the capability for complying with present and future environmental regulations. These planning activities are dependent on input from two major areas: a comprebensive characterization of the ORNL site and interfretation of current and proposed environmental legislation. Hence, the curreat Long-Range Plan is to be viewed as a summary of present plans, information, and understanding. The plan will be updated annually to report accomplishments, plans, and current scope. As part of this comprehensive planning effor, an environmental and waste management approach has been adopted by DOE for ise at all of its facilities in planning environmental upgrade and waste management activitie. This approach results in six major subprograms: (1) Comprehensive Environmental Management Program, (2) Air Pollution Control Program, (3) Water Pollution Control Program, (4) Solid Waste Management Program. (5) Remedial Action Program, and (6) Environmental Monitoring Program. The status of each of these subprograms is presented in the following sections.

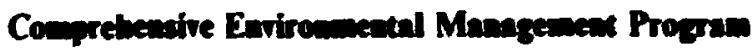

Development of the capabilities necessary for ORNL to achieve and maintain full compliance with environmental regulations requires the integration of a large number of individual projects and activities. The Comprehensive Environmental Management Program is comprised of the following activities:

- Long-Range Planning

- Low-Level Waste Disposal Development and Demonstration (LLWDDD) Program

- Environmental Monitoring and Compliance

- Comprehensive Project Tracking and Database Manageirent System

- Quality Assurance

- Waste Reduction/Recycle Activities

- Comprehensive Employee Training Programs

Emphasis is currently being placed in the areas of long-range planning, regulatory documentation, database management, and waste-reduction initiatives. Program planning and permit development activities have resulted in issuance of numerous regulatory and support documents during the past year related to the Resource Conservation and Recovery Act (RCRA). the National Pollutant Discharge Elinination System (NPDES) permit, the Clean Air Act (CAA) 
permit reviews and permit application development, routine National Environmental Policy Act (NEPA) document preparation for construction projects, and the ORNL Long-Range Environmental and Waste Management Plan. Many of these planning exercises have utilized or provided input to the expanding program database system for project tracting. Significant waste rolume-reduction activities are also under way in an effort to reduce impacts on the existing waste L...anagement systems.

The purpose of the LLWDDD Program is to plan for and guide the development of aew and improved waste disposal facilities for management of solid low-level wastes (LLW) generated on the Oal Ridge Reservation (ORR). This program is necessary both because curreat disposal capacities are being exhausted and becsuse improved waste management practices are required to meet regulatory requirements. Since the LLWDDD Program is applicable to the tirree major installations on the ORR, it is implemented via a core program which is conducted by the Waste Management Technology Center. Altbough the core program is not an ORNL responsibility, its central importance to management of ORNL solid LLW necessitates its coverage in the ORNL Environmental and Warte Management Long-Range Plan Implementation of those aspects of the overall LLWDDD strategic plans that are site-specific to ORNL is an ORNL responsibility.

\section{At Polmation Comtrol Pregram}

Air pollution control at ORNL involves consideration of sma!l local releases as well as monitoring and emission control for large central ventilation systems. An extensive Off-Gas and Cell Ventil: :ion System provides negative-pressure-based sontainment for Laboratory buildings and processes. This system has been in operation throughout the history of the Laboratory and has recently been upgraded. Other potential sources of air pollution are generally small, with the exception of the ORNL steam plant. Emissions from this source are controlled by common industrial equipment and practices. The research nature of ORNL does not involve significant production processes, which typically require permitting and control for gascous emissions; however, the potential for significant emissions from smaller-scale processes and activities is a concern.

Air pollution control activities involve continued upgading of the major air pollution control systems, as well as continued development and maintenance of a database of potential air pollutants at ORNL. Activities focus on identifying problems related to inflow, infiltration, and exfiltration of groundwater and surface water in the underground ductwork, ind renovation of systems will continue as necessary. Changes in regulations and the implementation of ALARA policies will likely result in additional activities necessary to minimize air pollution from ORNL facilities.

\section{Water Pollation Coatrol Propran}

ORNL activities generate six basic wastewater streams that could result in water pollution: (1) radioactive LLW; (2) process waste (PW); (3) wastes from area sources that are comprised of storm sewer collection from general-use areas (such as buildings, roads, and parking areas), contaminated areas such as the liquid low-level radioactive waste (LLLW) tank farms, and contaminated groundwater; (4) point sources, which include coal yard runoff and discharges from cooling towers; (S) sanitary wastes, which consist of typical industrial sanitary sewage from Bethel and Melton valleys, where approximately 5200 people are employed; and (6) ORNL facilities at the Oak Ridge Y.12 Plant. The Water Pollution Control Program focuses on the control and treatment of liquid wastes produced by ORNL, as well as the activities and systems that have the 
potential for polluting ground and surface waters at ORNL. Noaradioactive hazardous wastes are effectively segregated from liquid waste streams at the generation source and, thus, liquid waste streams require treatment primarily for radioactivity and some minor chemical contamination such as organics and heavy metak. Lower-activity waste is treated for removal of radioactivity prior to release into surface streams through an NPDES discharge point, and highet-activity radionctive wastes are concentrated and stored for future treatment and dispusal.

Planning in the Water Pollution Control Program emphasizes volume reduction, additioaal treatment and monitoring, solidification of LLW streams, and implementation of the bers: manafement practices" (BMP) philosophy for all systems. New facilities will improve the management of water pollution. These facilities are the completed improvements to the Sewage Treatment Plant, which has reduced the frequency of moncompliance, and a Noaradiological Wastewater Treatment Plant (NRWTP) to be in operation by 1990, which will treat nsaradionctive process wastes for removal of minor chemical coniamination prior to release through a permitted NPDES peint. The NRWTP will receive and treat process wastes directly from Laboratory operations as wall as waste streams that have been pretreated for removal of low-level radioactivity. Research, der 'opment, demonstration, and construction are under way to define and implement solidification procesces for higher-activity wastes that are presently stored in tanks with limited capacity. The implementation of BMP will include not only replacement of existing deteriorated systems, such as the LLW collection system, but also rebabilitation of existing piping systems to reduce inflow and infiltration. Rehabilitation via in situ lining of underground piping has been completed in the sanitary sewage collection system and is being conducted in the PW system. BM:P implementation will also involve increased definition and understanding of waste generation processes and facilities through surveys, building drain inventories, systems analyses, identification and segregation of system crous-connections, and operational and process changes. Major sources of nitrate discharges to the watershed have been eliminated. The Water Pollution Control Program will be affected significantly by decisions made in conjunction with RAP regarding the continued and future treatment of contaminated groundwater and disposition of wastes generated by decommissioning inactive LLW tanks.

\section{Solsd Waste Masagement Progran}

Solid waste management at ORNL encompasses the collection, handling, treatment, storage and disposal of radioactive, nonradioactive, hazardous, mixed (hazardous and radiozctive), and conventional wastes. Solid waste management has historically been accomplished predominately via shallow land buria!. Regulatory and policy changes have resulted in the requirement to segregate certain types of waste such as transuranic (TRU), hazardous, and mixed wastes. Greater confinement disposal (GCD) is now being practiced for LLW.

The strategy for management of solid wastes is to avoid the previous practice of shallow land disposal involving the placement of waste in direct contact with soil. Waste volume reduction and source generation reduction are being emphasized both in central facilities and at the generation source. Interim storage for the significant portion of the radioactive solid wastes is planned until acceptable permanent disposal methods are defined, especially for those materials classified as hazardous and radioactive. Improved confinement for disposal in the existing Solid Waste Storage Area (SWSA) 6 disposal area has been initiated, while interim storage, stabilization, and treatment is being utilized in the multiyear LLWDDD Program. This program is designed to define the facilities and processes necessary for effective management of low-level radioactive wastes on the ORR. 
The development of groundwater compliance requirements by the state of Tunessee will be a major factor and influence in derelopment of the LLWDDD and other solid waste disposal methods. Interim storage of TRU wastes wiil continue with necessary activities for repackaging and certification for dsposal at the Waste Isolation Pilot Plant (WIPP) and some consideration for develepment of on-site disposal options for difficult-to-certify, remote-handled wasies. Hazaroious and mixed waste management will focus on development of treatment capabilities to render the waste nonhazardous. Some oif-site shipmerts of hazardous waste will continue subject to the minimization of the long-term liabilities unherent in such disposal. In general, future waste handling and dispusal and other BMP will be internalized to the extent gossible.

\section{Remedial Action Propram}

Past research, development. and waste managenent activities have produced a numbur of surplus, inactive facilities contaminated with LLW and/or hazardous chemical wastes, as well as areas of off-site contamination. Such sites include SWSAs, waste ponds and seepage pits, radioactive waste processirg and transfer facilities, research laboratories, dedicated environmental research areas, experimental reactors, radioisotope development facilities, as well as the areas surrounding these sites and off-site contamination in the Clinch-Iennessee rivers. Monitoring and control of these areas have been continuing responsibilities of the Laboratory to ensure that ORNL personnel exposures and off-site releases are maintained within applicable DOE guidelines. Environmental legislation enacted at the state and federal levels requires more comprehensive control over facility discharges and the cleanup of contaminated sites. The most important of these regulations are the RCRA (including the 1984 Hazardous and Solid Waste Amendments): Comprehensive Environmental Response, Compensation, and Liability Act (CERCLA); Superfund Amendments and Reauthorization Act of 1986 (SARA); Clean Water Act (CWA); and the Saie Drinking Water Act (SDWA). In the near term, the RCRA and CWA regulations have had significan: impacts on the RAP through requirements associated with the RCRA and NPDES permits for ORNL. Under the 1984 Hazardous and Solid Waste Amendments, regulations have beell (or are being) promulgated for management and closure of facilities containing hazardous wastes. Of particular significance to the RAP are both specific requiru,nents for landfills (e.g., affecting SWSA 6) and underground storage tanks and the more general provisions for assessment and corrective actions at sites found to be sources of continuing contaminant releases to the erivironment [Sections $3004(u, v)$ of RCRA].

The RAP has currently identified 164 sites in 13 basic categories that require some degree of reinedial action or evaluation. These sites range in complexity from abanooned waste storage ponds and tanks to large experimental reactors and waste disposal sites. Some activity is under way at all of these sites, either through site characterization and assessment, routine maintenance and surveillance, corrective actions, or facility decommissioning. Current priorities and funding allocations have been established to provide continuing protective storage for all sites, to correct deficiencies in regulatory compliance, to reduce known sources of environmental contamination, and to deconuminate facilities to allow heneficial reuse.

\section{Environmental Monitoring Program}

A key element of the implementation of all suhprograms will he an effective environmental monitoring program. Fenvironmental monitoring at ORNI. includes survellance of air quality. 
surface-water quality, and groundwater quality. Implementation of this system involves not only the location and operation of appropriate sensor devices but also the facilities and equipment for receipt and presentation of the data and appropriate moieling and predictive capability.

The Environmental Monitoring Program emphasizes two major areas: upgrading of existing deterioriated or unacceptable equipment and upgrading of the monitoring system to provide additional capability to meet increased regulatory requirements. Until recently, much of the air and surface-water monitoring capability was inadequate both functionally and from a maintenance perspective. The ORNL NPDES permit requires additional monitoring point: and capability. Substantial upgrading of the environmental monitoring system has been achieved and improvements will continue to achieve and maintain compliance.

Additional emphasis on RCRA-directed groundwater monitoring requirements for chemical contamination will also require significant expansion of the total monitoring system. A total of 332 piezometer wells have been completed by the RAP and are being utilized for data acquisition, and about INJ groundwater quality wells have been installed. It is anticipated that several hundred additional groundwater quality wells will be required at ORNL to characterize and monitor facilities in accordance with environmental regulations. Although these and subsequent groundwater quality wells are being implemented by the RAP as part of the site characterization activities, some of the groundwater quality wells will be used subsequently on a longer-term basis for routine compliance monitoring.

\section{PROGRAM BUDGET SUMMARY}

Based on the program strategy' outlined in this ORNL Long-Range Environmental and Waste Management Plan, preliminary cost estimates have been developed for completion of the required comprehensive environmental restoration and facilities upgrade activities at ORNL. As shown in Table 1.1, significant resource allocations will have to be made by DOE in several major program categories to ensure upgrading of the waste management systems to necessary levels of operation and ade, wate environmental monitoring for determining compliances and to provide for corrective actions at contaminated sites. Alt'lough annual funding needs have been outlined only for the near term (FY 1988 through FY 199\%), the total estimated costs have also bren included to provide a picture of the anticipated out-year requirements. Estimates have been made of both the expense and capital resource cominitments that are needed to adequately support the implementation of environmental restoration efforts. As currently outlined, this commitment is expected to exceed $\$ 1.4$ billion in unescalated current-year dollars over the lifetime of the effort. The majority of this commitment (over $\mathbf{S 1}$ billion) is associated with implementation of the comprehensive RAP. The preliminary cost estimates for these corrective actions are based primarily on the concept of in situ stabilization of the residual contamisation, where feasible. Significant increases in these costs would be expected if extensive excavation and removal of these materials are required due to regulatory requirements.

In addition to the environmental restoration and facilities upgrade activities discussed above (which ais funded by several DOE programs), ongoing routine operations are conducted at ORNL in the areas of (1) waste management operations and (2) environmental monitoring and compliance.

Funding for operating the facilities necessary for ORNL waste management is derived in part currently by allocating these costs to generators of specific waste streams. The remainder of the 


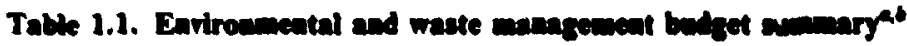

(millions of dollars)

\begin{tabular}{|c|c|c|c|c|c|c|c|c|c|c|}
\hline \multirow{2}{*}{\multicolumn{2}{|c|}{ Program category }} & \multicolumn{8}{|c|}{ Fiscal year } & \multirow{2}{*}{$\begin{array}{c}\text { Total } \\
\text { estimated } \\
\text { coste }^{\circ}\end{array}$} \\
\hline & & 1987 & 1988 & 1989 & 1990 & 1991 & 1992 & 1993 & 1994 & \\
\hline 1.0 & Coxiprehensive Environmental Management & 0.8 & 0.8 & 0.9 & 0.9 & 0.9 & 0.9 & 0.9 & 0.9 & 12.8 \\
\hline 2.0 & Air Pollution Control & 1.4 & 1.6 & 2.9 & 2.2 & 2.3 & 2.2 & 2.3 & 2.0 & 25.7 \\
\hline 3.0 & Water Pollution Control & 13.8 & 18.8 & 18.7 & 24.5 & 21.0 & 17.1 & 17.2 & 18.4 & 229.9 \\
\hline 4.0 & Solid Waste Management & 3.4 & 4.1 & 7.2 & 7.6 & 14.9 & 32.4 & 44.9 & 44.6 & 191.7 \\
\hline 5.0 & Remedial Action & 15.4 & 21.6 & 34.1 & 25.1 & 24.8 & 27.0 & 30.5 & 30.5 & 1071.3 \\
\hline 6.0 & Environmental Monitoring & 3.3 & 3.9 & 3.0 & 1.9 & 2.6 & 1.9 & 2.1 & 1.9 & 38.1 \\
\hline & $\begin{array}{l}\text { Total } \\
\text { Total FY 1987-1994: } 562.1\end{array}$ & 38.1 & 50.8 & 66.8 & 62.2 & 66.5 & 81.5 & 97.9 & 98.3 & 1569.5 \\
\hline
\end{tabular}

-Figures roundod off to nearest 50.1 million.

Funds for routine operations on waste management conducted by WMO, routine compliance monitoring conducted by EMC, and the LLWDDD core program conducted by the Waste Management Technology Center (WMTC) are not included in this table and are summarized in Table 1.4

Tncludes funding for years precediug 1987 and beyond 1994. 
funding is provided by the DOE Office of Defense Waste and Transportation Management; however. no funding is planned from this source after FY 1988. Further information concerning funding for waste management operations is provided below in the section entitled -Waste Disposal Costs."

Funding for routine environmental monitoring and compliance activities is provider from ORNL overhead, and frither information is provided below in the section entitled "Environmental Monitoring and ('ompliance Costs."

The cost ank schedule extimates presented in this Plan are based on adherence to current regulatory and lizal requirements as well as protection of the environment and bealth and safety. Compliance schedules that are only now being developed can be expected to impact significantly the planning and implementation of the proposed facilities upgrade and environmental restoration artivities. As changes occur in the current regulations or in the way in which these regulations are applied to DOE sites like ORNL, similar revisions would be expected in the Program scope and schedules. In addition, the current cost estimates are based on preliminary and often incomplete characterization and assessment data and on action plans that have not received regulatory approval. Hence, these scoping estimates need to be viewed as order of magnitude only. As regulatory requirements are better defined and project plans are further developed, these estimates will be refined.

\section{Waste Disposal Coats}

The treatment, itorage. ind/or dispusal (TSD) of radioactive, hazardous, and mixed wastes generated at ORNL are inducted by the WMO Program and have historically been directly funded by either a DOE programmatic sponsor or Laboratory overhead. Waste gencrators were therefore insulated from vaste management costs and issues, which resulted in an "insensitivity" to the volumes and types of wastes generated. With the recent emphasis on disposal of hazardous and radioactive wastes in accordance with new and more stringeni regulatory requirements, the benefits of waste minimization became obvious. In December 1985, ORNL. was requested by DOE-ORO to develop and implement a cost recovery (charge-back) plan for TSD waste operations. The purpose of instituting a cost recovery program was to effect waste minimization through direct charges to generators for TSD of the waste they generate.

A charge-back plan was developed and ultimately approved in April 1986. The plan allows for a gradual shifting of operational charges from programmatic sources to waste generators over a period of three fiscal years. The shift began in FY 1986 and will be completed by the end of FY 1988. There is to be no programmatic funding of TSU waste operations beginning in FY 1989. The bdsis for charge-back is reviewed annually to incorporate additional costs associated with waste handling techniques, which are being improves. and costs associated with regulatory requirements, which are being incorporated into waste handling practices. The logic network used to establish the basis for charging waste generators is shown in Fig. 1.1. Estimated waste disposal costs to be funded by charge-back are summarized in Table I.2.

Generators are charged for direct TSD operations and routine maintenance only, not for waste management R\&D, capital equipment replacement, or capital improvements to TSD facilities which is accomplished via general plant projects (GPPs) or line item projects (LIPs). 


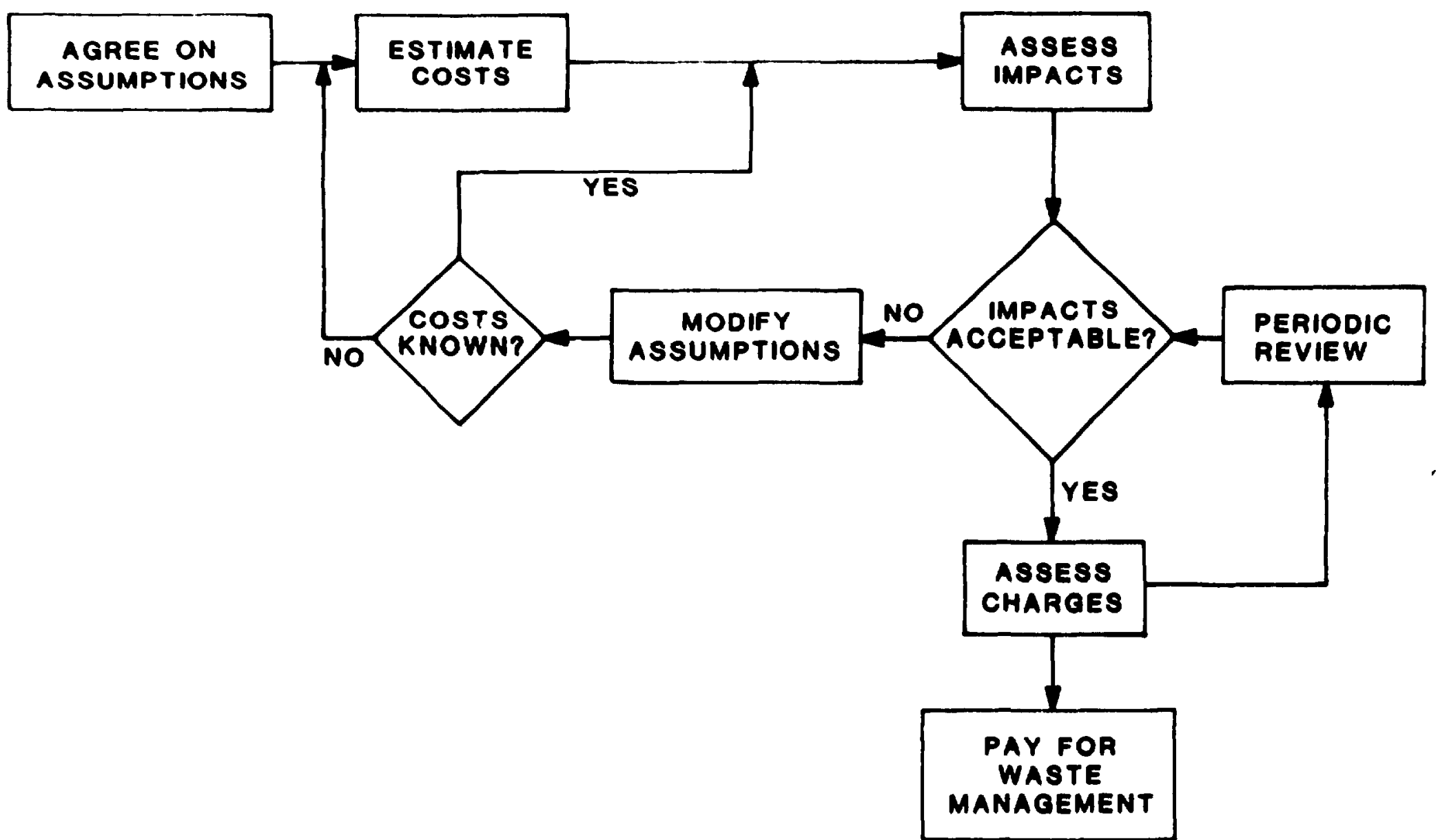


Talie 1.2. Eotimated wate diecoed conts

(thousands of dollars)

\begin{tabular}{|c|c|c|c|c|c|c|c|c|c|}
\hline \multirow{2}{*}{$\begin{array}{l}\text { WBS } \\
\text { category }\end{array}$} & \multicolumn{8}{|c|}{ Fiscal year } & \multirow{2}{*}{$\begin{array}{c}\text { Tolal } \\
\text { FY 1987-FY } 1994\end{array}$} \\
\hline & 1987 & 1988 & 1989 & 1990 & 1991 & 1992 & 1993 & 1994 & \\
\hline $\begin{array}{l}\text { Air } \\
\text { (radionctive } \\
\quad \text { gas) }\end{array}$ & 520 & 650 & 995 & 1,092 & 1,092 & 1,092 & 1,092 & 1,092 & 7,625 \\
\hline $\begin{array}{l}\text { Liquid } \\
\text { (radioactive } \\
\text { liquid) }\end{array}$ & 2,860 & 3,900 & 5,635 & 6,188 & 6.188 & 6,188 & 6,188 & 6,188 & 43,335 \\
\hline $\begin{array}{l}\text { Solid } \\
\text { (radioactive, } \\
\text { hazardous, } \\
\text { mixed, and } \\
\text { conventional) }\end{array}$ & $\therefore 990$ & 3,840 & 4,290 & 4.680 & 4,680 & 4.680 & 4.680 & 4,580 & 34,520 \\
\hline Tolal & 6,370 & 8,390 & 10,920 & 11,960 & 11,960 & 11,960 & 11,960 & 11,960 & 85,480 \\
\hline
\end{tabular}

Includes solid, liquid, and gaseous states.

Notes: All estimates in FY 1988 dollars (except I Y 1987). All numbers include 30\% overhead. 
Not all waste streanis defined in the Long-Range Plan are intended to be covered by the cost recovery ?lan. The waste streams included in the current charge-back plan are:

1. Radioactive gascous waste (Cell Ventilation and Off-Gas)

2. Radioactive liquid waste (Process and Low-Level)

3. Radioactive solid waste

4. Hazardous solid, liquid, and gaseous waste

5. Mixed solid, liquid, and gaseous waste

6. Conventional solid waste (excluding sewage)

Charges for monitoring required to maintain process control in the liquid and gaseous treatment facilities are included in 1 and 2.

\section{Enviromaseal Monitorieg and Complinace}

Environmental surveillance and other activities associated with determination of whether ORNi is in compliance with environmental regulations, guides, and DOE Orders is conducted by the EMC Departmen'. within the EC\&HP Division and is funded from ORNL overhead funds. Environmental surveillance activities consist of the following activities:

- Data management and analysis

- Sample processing

- Data analysis and reporting

- Permitting and regulatory interpretation

- Environmental sampling

- Compliance reporting

- Monitoring instrumentation evaluation

- Field oversight

- Project planning and criteria review

Actual and projected environmental surveillance costs are summarized for each of these activities for the period FY 1987 through FY 1994 in Table 1.3.

Past and p.ojected funding for waste management operations, environmental surveillance, and the LLWDDD core program is summarized in Table 1.4. Table 1.5 shows the Environmentai and Waste Management Program by funding type with accunulative totals. 


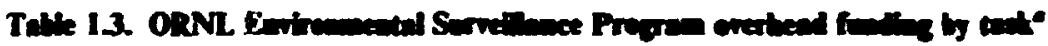
(thousands of dollars)

\begin{tabular}{|c|c|c|c|c|c|c|c|c|}
\hline \multirow{2}{*}{ Task } & \multicolumn{8}{|c|}{ Fiscal year } \\
\hline & 1987 & 1988 & i989 & 1990 & 1991 & 1992 & 1993 & 1994 \\
\hline $\begin{array}{c}\text { Datd Mongement } \\
\text { a ut Aralysis }\end{array}$ & 401 & 416 & 429 & 442 & 456 & 470 & 485 & 500 \\
\hline Sampi: Proceacing & 828 & 940 & 1016 & 1262 & 1438 & 1482 & 1526 & 1572 \\
\hline $\begin{array}{l}\text { Data inalysis and } \\
\text { Reporting }\end{array}$ & 94 & 128 & 132 & 136 & 140 & 145 & 150 & 155 \\
\hline $\begin{array}{l}\text { Permitting and } \\
\text { Regulatory } \\
\text { In'erpretation }\end{array}$ & 300 & 311 & 321 & 331 & 341 & 352 & 303 & 374 \\
\hline $\begin{array}{l}\text { Favironmental } \\
\text { Sampliag }\end{array}$ & 774 & 804 & 849 & 969 & 1058 & 1090 & 1123 & 1157 \\
\hline $\begin{array}{l}\text { Cimoliance } \\
\text { Repo.ting }\end{array}$ & 149 & 155 & 160 & 165 & 170 & 176 & 182 & 187 \\
\hline $\begin{array}{l}\text { Moritoring } \\
\text { Instrumentation } \\
\text { Evaluation }\end{array}$ & 480 & 500 & 515 & 531 & 547 & 564 & 581 & 598 \\
\hline Fictd Overnight & 220 & 288 & 297 & 306 & 316 & 326 & 336 & 346 \\
\hline $\begin{array}{l}\text { Project Planniog } \\
\text { and Criteria } \\
\text { Reriew }\end{array}$ & 31 & 32 & 33 & 34 & 35 & 36 & 37 & 38 \\
\hline Treal & 3227 & 3574 & 3752 & 4176 & 4501 & 4641 & 4783 & 4927 \\
\hline
\end{tabular}

Does not include funding for Environmental Review and Documentation Program (ERDP) which is funded via charge-back to customers. 


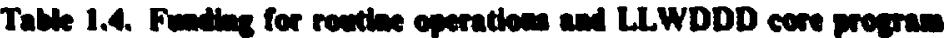

(thousands of dollars)

\begin{tabular}{|c|c|c|c|c|c|c|c|c|c|}
\hline \multirow{2}{*}{ Activity } & \multicolumn{8}{|c|}{ Fiscal year } & \multirow{2}{*}{$\begin{array}{l}\text { Total } \\
\text { FY } 1987- \\
\text { FY } 1994\end{array}$} \\
\hline & 1987 & 1988 & 1989 & 1990 & 1991 & 1992 & 1993 & 1994 & \\
\hline $\begin{array}{l}\text { Waste Management Operati } \\
\text { ONLWN01 (Expense) } \\
\text { ONLWN10 (Expense) } \\
\text { Charge-back } \\
\text { ONLWNOI (GPE) }\end{array}$ & $\begin{array}{r}5.481 \\
90 \\
6.370 \\
35\end{array}$ & $\begin{array}{r}3.433 \\
8.390 \\
300\end{array}$ & $\begin{array}{r}10,920 \\
444\end{array}$ & $\begin{array}{r}11.960 \\
450\end{array}$ & $\begin{array}{r}11,960 \\
450\end{array}$ & $\begin{array}{r}11,960 \\
450\end{array}$ & $\begin{array}{r}11,960 \\
450\end{array}$ & $\begin{array}{r}11,960 \\
450\end{array}$ & $\begin{array}{r}8,914 \\
90 \\
85,480 \\
3,029\end{array}$ \\
\hline Environmental Surveillance & 3.227 & 3.574 & 3.752 & 4,176 & 4,501 & 4,641 & 4,783 & 4,948 & 33,602 \\
\hline LLWDDD Core Program & 3,287 & 4,984 & 8,692 & 9,500 & 9,500 & 8,500 & 7,500 & 6,500 & 38,463 \\
\hline Total & 18,490 & 20,681 & 23,808 & 26,086 & 26,411 & 25,551 & 24,693 & 23,858 & 189,578 \\
\hline
\end{tabular}




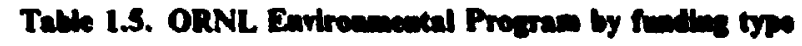

\begin{tabular}{|c|c|c|c|c|c|c|c|c|c|c|}
\hline \multirow{2}{*}{ Funding type } & \multicolumn{8}{|c|}{ Fiecal year } & \multirow{2}{*}{$\begin{array}{c}\text { Tolal } \\
\text { FY 1987-1994 }\end{array}$} & \multirow{2}{*}{$\begin{array}{l}\text { Total } \\
\text { extimated } \\
\text { cost }\end{array}$} \\
\hline & 1987 & 1988 & 1989 & 1990 & 1991 & 1992 & 1993 & 1994 & & \\
\hline GPP & 6.000 & 5,655 & 8,700 & 7.500 & 6,000 & 7,000 & 7,000 & 7,000 & 54,855 & 73,108 \\
\hline GPE & 2,019 & 1,513 & 1,148 & 1,360 & 1,330 & 1,255 & 1,230 & 1,230 & 11,085 & 28,748 \\
\hline LIP & 7,000 & 12,800 & 11,813 & 16,300 & 23,200 & 36,900 & 49,600 & 50,000 & 207,613 & 266,142 \\
\hline EXP & 23,027 & 30,870 & 45,155 & 37,064 & 35,982 & 36,361 & 40,022 & 40,022 & 288,503 & $1,201,454$ \\
\hline $\begin{array}{l}\text { Total } \\
\text { Accumulative total }\end{array}$ & $\begin{array}{l}38,046 \\
38,046\end{array}$ & $\begin{array}{l}50,838 \\
88,884\end{array}$ & $\begin{array}{r}66,816 \\
155,700\end{array}$ & $\begin{array}{r}62,224 \\
217,924\end{array}$ & $\begin{array}{r}66,512 \\
284,436\end{array}$ & $\begin{array}{r}81,516 \\
365,952\end{array}$ & $\begin{array}{r}97,852 \\
463,804\end{array}$ & $\begin{array}{r}98,252 \\
562,056\end{array}$ & 562,056 & $1,569,432$ \\
\hline
\end{tabular}




\section{INTRODUCTION}

Over the past several years, significant environmental legislation has been enacted at both the state and federal levels for controlling existing and potential sources of pollution. As part of this changing regulatory eavironment, inspections, audits, and reviews by personnel from the EPA, state of Tennessee, DOE-ORO, and DOE-Headquarters have focused attention on environmental issues at ORNL. The reports generated by these inspections emphasized the need to reduce hazardous chemical and radionuclide discharges to the environment and to accelerate environmental compliance activities on a more comprehensive basis. The inspections identified the need to correct those current practices, which in many cases provide inadequate treatment of discharges, and to address carlier disposal practices, which now affect the environment in and around ORNL. Because the Laboratory is not in full compliance with some current regulations and guidelines, timely action is required to bring ORNL into conformance with these regulations.

Three major programs, the ORNL Remedial Action Program (RAP). the Waste Management Operations (WMO) Program, and the Environmental Projects (EP) Program, have been eatablished at ORNL for implementation of facilities upgrade activities and site remedial actions necessary to give the Laboratory the capability for continued protection of the environment and health and safety of personnel and compliance with the applicable environmental regulations. The WMO Program identifies needed facilities and upgrades for ORNL radioactive and hazardous waste management systems. The EP Program implements and manages capital- and expense-funded projects to achieve improvements. Remedial actions will be conducted at locations where past waste management practices or research activities have resulted in contamination of facilities or the environment to levels that necessitate corrective actions. Routine waste management operations are provided through the WMO Program as part of its mission to operate the liq ild, gaseous, and solid waste systems at the Laboratory. Routine environmental compliance monitoring is provided through the EMC Department of the EC\&HP Division.

To provide effective management of the extensive environmental restoration, facilities upgrade. and other environmental activities to be conducted over the next several years, comprehensive longrange planning is escential. Strategies have been developed that (1) outline the scope of needed improvements; (2) identify specific projects that must be implemented; (3) determine the priorities of these projects based on regulatory compliance, health and safety concerns, schedule and budget constraints, and other programmatic considerations; and (4) develop overall cost and schedule estimates for use in budget requests to DOE. These strategies are continuing to de updated. They are included in this Plan along with identification of projects necessary for implementation of these strategies. The planning activities to be conducted over the next few years will be the most crucial in defining the scope of work necessary to provide ORNL the capability to comply with present and future regulations. The strategies for this compliance capability have been formulated, and specific project-level information is included. As plannir.g and strategy development continues over the next 
several years, an updated program-level ORNI. Long-Range Environmental and Waste Management Plan will continue to be issued annually to provide the latest information.

A comprehensive management structure has been adopted by DOE-ORO for use in planning for environmental restoration and facilities upgrade activities at all of the DOE-ORO facilities. It consists of six major program categories: Comprehensive Environmental Management Program, Air Pollution Control Program, Water Pollution Control Program, Solid Waste Management Program. Remedial Action Program, and Environmental Monitoring Program.

The ORNL Long-Range Environnental and Waste Management Plan provides a program overview and summary information, focusing on relevant regulatory requirements for each of the six major program areas, development of overall strategy, and scoping of program costs and schedules. The information provides insight into the magnitude and direction that will characterize the program over the next several years. 


\section{COMPREHENSTVE ENVIRONMIENTAL MANAGEMINT PROGRAM}

Development of the capabilities necessary for ORNL to adequately protect the environment and the health and safety of on-site workers and the public as well as attain full compliance with environmental regulations requires the integration of a large number of individual projects and actuvities. To effect overall integration of work and to allow for effective long-range planning. overall budget control and development, and proper project scheduling and tracking, seven activities have been initiated that comprixe the Comprehensive Environmental Management Program. These activities include:

- Long-Range Planning

- Low-Level Waste Disposal Develcpment and Demonstration (LLWDDD) Program

- Envirunmental Monitoring and Compliance

- Comprehensive Project Tracking and Database Management System

- Quality Assurance

- Waste Volume Reduction and Recycle Activities

- Comprehensive Employee Training Programs

One of these activities, LLWDDD Program, is conducted in part through a core program which is not an ORNL responsibility. However, the cen:ral importance of the core program to management of ORNL solid LLW necessitates its coverage in this Long-Range Plan. Implementation of those aspects of the overall LLWDDD strategic planning that are site-specific to ORNL is an ORNL responsibility.

Implementation of these activities is under way, with particular emphasis in the areas of longrange planning. regulatory documentation, database management, and waste reduction activities. These activities are summarized briefly in this chapter.

\section{LONGRANGE PLANIJING}

A comprehensive long-range planning function has been established to allow ORNL to be fully responsive to its environniental protection needs, including compliance with applicable environmental regulations. For each of the five principal subprograms (Air Pollution Control, Water Pollution Control, Solid Waste Management, Remedial Action, and Environmental Monitoring) a strategy document was written in FY 1986, was updated in FY 1987, and will be updated further as required. Major environmental needs, their relative priurities for facilities upgrade, remedial actions or other environmental activities, and projects for implementing the strategy have been identified, characterized, and prioritized relative to cost and schedule. 
The long-range planning function is based on the approach outlined in the strategy documents for the respective subprograms and will utilize this information in conjunction with an overall prioritization to assemble an owerall comprehensive plan for all program areas at the ORNL site.

\section{LWWDDD PROGRAM}

The purpose of the LLWDDD Program is to develop new and improved waste disposal facilities for the management of low-level solid wastes generated on the ORR. The task is needed both because current disposal capacities are being exhausted and because improved waste management practices are required to meet regulatory requirements.

The scope of the LLWDDD Program encompasses the following:

- developing and securing approvals for a low-level waste management strategy for the ORR;

- assisting sites in the development of site-specific LLWDDD strategy implementation plans and assisting the Central Waste Management Office by reviewing these plans and integrating them into an overall LLWDDD plan;

- defining the functional requirements for new disposal facilities (to inciude characteristics of waste streams or waste packages to be routed to the disposal facilities, schedule for needed new disposal capacity for various waste streams or waste packages, and performance iequirements for disposal facilities);

- siting new disposal facilities ard satisfying NEPA requirements for disposal facilities;

- conducting demonstrations of treatment/packaging, storage, and disposal technologies to reduce technical and economic uncertainties associated with deployment of new disposal facilities;

- supporting improved LLW management operations cunducted by waste management organizations at plants on the ORR (to include assistance in the design of disposal facilities. development of monitoring plans, and evalution of performance); and

- preparing new sites and constructing new disposal facilities for operation by waste management i rganizations at plants on the ORR. The installation at which a new facility will be constructed will be responsible for obtaining funds and managing the construction project.

Current planning is based on beneficial occupancy of new prototype waste disposal facilities on the ORR by September 30, 1991. These facilities will be built by eact of the plants (i.e., ORNL, $Y-12$, and $K-25$ ) and will encompass a complex of sites and disposal technologies representing best management practices for the different low-level wastes handled in the facilities. These disposal operations will be treated as demonstrations for an indefinite period of joint assessments by Energy Systems, DOE, and regulatory agencies.

The implementation of the LLWDDD strategy is the responsibility of each ORO site and is specified in their site-specific LLWDDD implementation plans. These plans will identify the tasks and associated budget for the LLWDDD implementation. These funds are in addition to the funding provided for the core LLWDDD program. The core program addresses the issues mentioned above for all the sites on the ORR. The funding for the LLWDDD core progtam is summarized in Table 3.1 . 


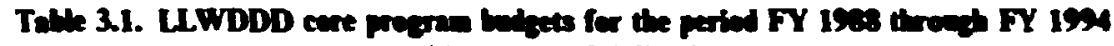
(thousands of dollars)

\begin{tabular}{|c|c|c|c|c|c|c|c|}
\hline \multirow{2}{*}{ Work element activity group } & \multicolumn{7}{|c|}{ Fiscal year } \\
\hline & 1988 & 1989 & 1990 & 1991 & 1992 & 1993 & 1994 \\
\hline 1.0 Progry n Planning and Management & 300 & 300 & 300 & 300 & 300 & 300 & 300 \\
\hline $2.0 \mathrm{NE}$.. Coordination & 2012 & 250 & 100 & 100 & $\mathbf{0}$ & $\mathbf{0}$ & $\mathbf{0}$ \\
\hline $\begin{array}{l}\text { 3.0 Technolozy Demoustration and } \\
\text { Ascessments }\end{array}$ & 1108 & 7142 & 8100 & $8: 00$ & 7200 & 6200 & 5200 \\
\hline Total operating costs $(B / O)$ & 4220 & 8692 & 9500 & 9500 & 8500 & 7500 & 6500 \\
\hline
\end{tabular}

\section{ENVIRONMENTAL MONITORING AND COMPLIANCT}

Environmental surveillance and other activities associated with determination of whether ORNL is in compliance with environmental regulations, guides, and DOE Orders are conducted by the EMC Department within the EC\&HP Division and are funded from ORNL overhead funds. Environmental surveillance activities consist of the following:

- Data management and analysis

- Sample processing

- Data analysis and reporting

- Permitting and regulatory interpretation

- Environmental sampling

- Compliance reporting

- Monitoring instrumentation evaluation

- Field oversight

- Project planning and criteria review

Actual and projected environmental surveillance costs are summarized for each of these activities for the period FY 1987 through FY 1994 in Table 1.3.

Date Management and Analysis. This task includes database development and management for all environmental samples, statistical analysis of data, and assessment of the impacts of ORNL activities on the environment and the public. Other activities include maintenance for two computers for real-time data collection; maintenance of another computer for data storage, retrieval, management, and analysis; and analysis of data from over $\mathbf{2 0}$ monitoring stations. Staff supported under this task also perform backup of all computerized data, maintain the integrity of the computer systems, support user requests, install new software and software updates, coordinate the installation of new communications hardware, and implement and update automated data processing (ADP) protection plans.

Sample Processing. Staff supported under this task prepare samples for analysis and process and track all environmental samples and results. Successful performance of tasks requires coordination with five analytical laboratories for analysis of radioactive and nonradioactive samples. Included in this task is the archiving of samples and the development of quality assurance (QA) procedures and controls. QA activities include sample spiking, submission of blanks and standards, 
data verification, procedure verification and auditing, and operational periormance checks. Tinvely processing and analysis of samples is assured and the regulatory requirement for chain-of-cuet. Jdy control of environmental samples is fulfilled.

Dure Analysis and Reporting. Periodic reports are prepared and iscued on the data analysis and ascessment of radioactive and nonradioactive eflnuent streams as sequired by DOE, the state, and the EPA. Among the reports geserated are the following: quarterly data report for ORNL distribution, quarterly reports for EPA on groundwater monitoring, and monthly Discharge Monitoring Reports. Staff supported under this task are required to test data for compliance with applicable permits and report any violations within prescribed reporting time periods.

Penmitring and Regalatary Imerpretation. Under this task aporopriate documentation is prepared to ensure that all ORNL operations comply with the various federal and state environmental laws and regulisions. Responsibilities included in this task are (1) preparing appropriate jermits for compliance wit:i RCRA, CERCLA, TSCA (Ti)xic Substance Control Act of 1976), CWA, and CAA: (2) informing ORNL management of changes in enviroomental laws which will impact operations; (3) acting as ORNL's point of contact with state and federal agencies, DOE, and Martin Marietta Energy Systems staff; and (4) determining the need for monitoring activities called for by compliance requirements.

Environmental Sampling. Environmental sample collection and other monitoring services are provided to demonstrate compliance with pertinent DOE Orders such as DOE Orders 5540.1BN, 5484.1, 5830, snú EPA laws such - LAA, CWA, RCRA, SDWA, and state of Tennescec laws such as the Tennessee Air Quality Act. Atmospheric, aquatic, terrestrial, biological, and foodstuff samples are collected for radiological and nonradiological monitoring. Staff supported under this task also provide services to determine environmental impact from ORNL operations.

Compliance Reporting. Under this task reports are prepared as required by DOE, EPA, and the state of Tennessee. Each egulatory agency requires regular non 'ompliance reports of findings as part of compliance activities. Environmental assessments are prepared as required by DOE Order 5440.1C and NEPA. The assessments document the fact that Laboratory operations do not conflict with existing environmental laws or regulations.

Monitoring Instrumentation Evalwation Under this task management systems needed to monitor the environment and ORNL efluents are evaluated. Criteria and criteria review for instrument locations, frequency of measurements, and other instrument protocols are provided. Coordination for system maintenance and calibration is provided. The instrumentation systems to be maintained are numerous: meteorological towers, atmospheric monitoring stations, NPDES monitoring points, aquatic monitoring stations, groundwater wells, and other environmental measurement systems.

Field Oversight. Field level interface and oversight is provided for implementation of ADM (Action Description Memoranda), AcDM (Activity Description Memorandum), and ALARA guidelines to ORNL projects and operations. Compliance assessments are conducted for ORNL operations. Compliance oversight for ORNL remedial response is provided. Interface is carried out with ORNL divisions and with Y.12 and Oak Ridge Gascous Diffusion Plant (ORGDP) representatives on environmental protection, surveys and audits, and waste management functions for the ORNL facilities located at Y.12 and ORGDP.

Projert Planning and Criveria Review. Liaison is maintained with Central Staff, Engineering, Safetv, Fire Department, and ORNL R\&D divisions and programs on projects and activities proposed for ORNL to ensure compliance with DOE Orders, state of Tennessee and EPA 
regulations, ORNL ALARA guidelines, and corporate policies. Staff supported under this task review project criteria and engineering documentation/drawings for environmental concerns. Reviews are conducted on the design, construction, and operation of required pollution control, environmental monitoring, and sampling equipment.

\section{COMPREHENSIVE PROJECT TRACEING AND DATABASE MANAGEMINT SYSTEM}

A comprehensive project tracking and database management system has been developed and implemented for following the Remedial Action and Environmental Projects Programs addressed by the ORNL Long-Range Environmental and Waste Management Plan in terms of scheduling. funding, interrelationships between tasks, and important control points.

\section{QUALITY ASSURANCE}

The objective of the Nuclear and Chemical Waste (N\&CW) Programs Quality Assurance system is to develop, implement, and maintain QA practices that will ensure that all waste management projects are (1) conducted with the highest regard for the health and safety of personnel and the surrounding population, (2) designed and executed for both the short- and longterm protection of the environment, and (3) in compliance with state and federal regulatory requirements and sponsor requirements. An intense effort has been initiated to bring all programmatic elements into compliance with ANSI/ASME NQA-I Quality Assurance standards as mandated by DOE Order 5700.6 and the QA practices and procedures of Martin Marietta Energy Systems and ORNL. A Quality Assurance Handbook that provides rationale, policies, procedures, and instructions for the implementation of NQA-1 is under development. The Handbook will address all elements of the NQA-I standard and assure that all requirements are met. A Quality Assurance Assessment and a Risk Assessment will be made of each project, and project-specific Quality Assurance Plans will be developed and implemented. Audit, inspection, and surveillance activities will be an integral part of each project.

\section{WASTE VOLUME REDUCTION AND RECYCLE ACTTVITIES}

The ORNL strategy for dea ing with liquid and solid wastes includes activities that will reduce the volume of materials that must be handled. Some of the means to be considered include waste avoidance, material substitutions, process alterations, waste reduction, waste minimization, and waste recycle. Evaluation of concepts that can reduce waste volumes is continuing, including the recycle of selected efiluents. Systems for increasing the accountability of the waste generators through a charge based on volume of waste generated are being implemented.

\section{COMPREHENSIVE EMPLOYEE TRAIN: VG PROGRAMS}

Employee training programs are an important tool in improving the environmental compliance capabilities of the Laboratory; these are discussed in this Plan because of the close relationship between these training programs and activities covered within the Plan.

WMO and EMC employee training programs are integrated at ORNL as one part of the general strategy to improve environmental performance emphasizing coordination among the numerous divisions that are involved in these activities. The objective of the upgraded training 
program is to provide employees with the knowledge and stills needed to perform assigned duties in a safe and efficient manner.

A general employee training program has been developed to review the major health, safety, and emergency preparedness program at ORNL. The program was developed for administrati in by division safety officers. ORNL employees complete an awareness sheet that is signed by their supervisors to verify their participation in the program. Since implementation of the program two years ago, approximately $80 \%$ of the Laboratory employees have completed the program.

In keeping with DOE Order $5480.1 \mathrm{~A}$ and other associated contractual documents, the initial phase of qualification/documentation for radiation protection personnel was established. Review sessions were held, and written examinations were conducted. Radiation protection technicians and members of the professional staff completed their qualification requirements and were certified to perform their assigned duties.

Several health and environmental training programs for ORNL employees and other individuals associated with construction activities were established. A special training program for ORNL workers involved with construction projects was developed and implemented.

In order to comply with 29 CFR 1910.120 (SARA), a worker protection training program has been developed. The course was piloted in November 1987 and will be offered each month beginning in January 1988. 


\section{AIR POLLUTION CONTROL PROGRAM}

Air emission sources at ORNL are classified into three categories, as shown in Fig- 4.1. These categories are (1) radioactive emission sources, (2) emission sources that require state air permits, and (3) all other emission sources. Because most facilities at ORNL have been or are being used tor work related to nuclear exergy, radioactive emission sources are of primary importance. Emission sources that require state air permits (otiner than the ORNL steam plant) are generally small and do not require large pollution control equipment but must be identified, characterized, and in some cases permitted. Other air emission sources, not regulated by the CAA, have been identified but are not included in the Air Pollution Control Program. The major objectives of the program are

- to ensure that air emissions from ORNL facilities do not constitute a hazard to on-site workers, the public, or the environment and

- to ensure that air emissions from ORNL are in compliance with applicable regulations and satisfy DOE ALARA objectives.

Air emissions from ORNL facilities are managed in accordance with DOE Orders (5480.1A, 5480.4, 5820.2), and guidelines of the CAA as regulated by the TDHE Division of Air Pollution Control. TDHE has the primary responsibility for ensuring compliance with the CAA within the state of Tennessee and of protecting and maintaining Tennessee ambient air quality standards. Two of the main provisions of the CAA are (1) to establish ambient air quality standards for suspended particulates, sulfur dioxide, carbon monoxide, ozone, nitrogen dioxide, lead, and gaseous fluorides and (2) to establish National Emission Standards for Hazardous Air Pollutants (NESHAP) for air pollutants for which no air quality standard is applicable and which may result in an increase in mortality or reversible illness. Currently, NESHAP standards have been established for beryllium, mercury, vinyl chloride, asbestos, and radionuclides.

ORNL facilities produce air emissions regulated both by ambient air standards (called "criteria pollutants") and NESHAP standards, as illustrated by the air pollution control strategy outline in Fig. 4.2. Criteria pollutants are primarily associated with discharges from the steam plant. Radionuclides discharged through major ventilation stacks are the primary source of NESHAP pollutants. However, there are other emission urces located throughout ORNL that discharge small quantities of criteria and NESHAP pollutants.

Air emissions at OR.NL are in compliance with state and federal air quality standards. However, a concentrated effor has been directed at identifying and evaluating all air emission sources to confirm that they are in compliance with applicable regulations and to determine if upgrade or additional pollution control equipment is needed for continued satisfactory operation and performance. The central Cell Ventilation and Off-Gas System has recently been upgraded significantly via the Improvements of Radioactive Waste facilities LIP. A comprehensive survey of 


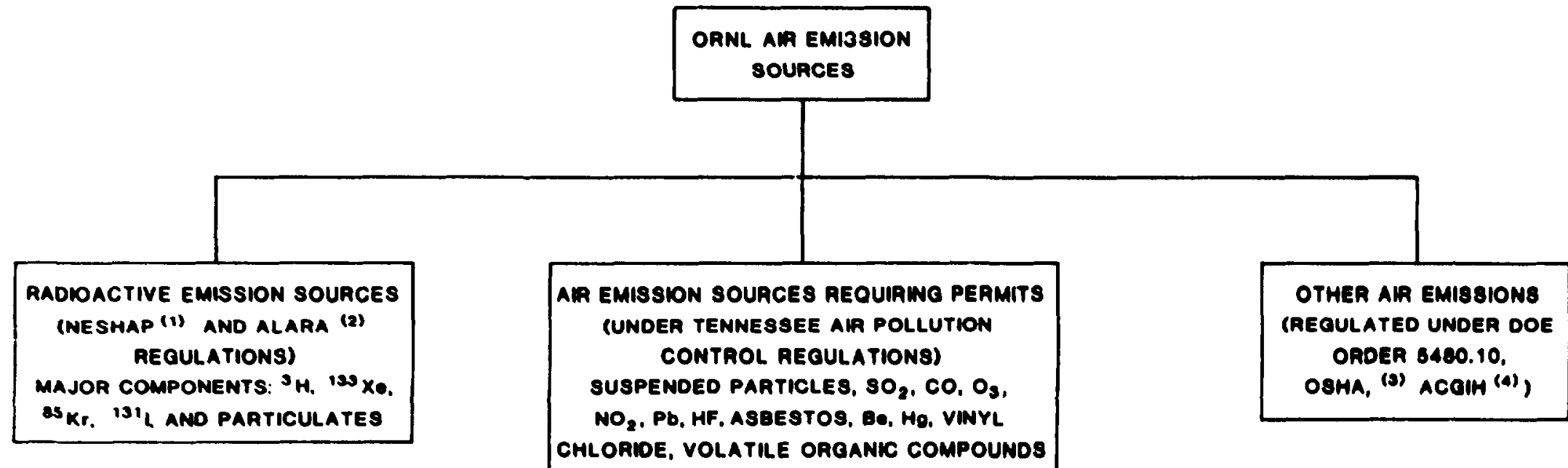

(1) NATHONAL EMISSION STAMOARDS FOR HAZARDOUS AIR POLLUTANTS

(2) AS LOW AS REASONABLY ACHIEVABLE; DOE ORDER 8480.1

(3) OCCUPATIONAL SAFETY AND HEALTH ADMHISTRATION

(4) AMERICAN CONFERENCE OF GOVERMMENTAL MDUSTRIAL HYGIENISTS

Fi. 4.1. Enimalon sources at ORNL. 


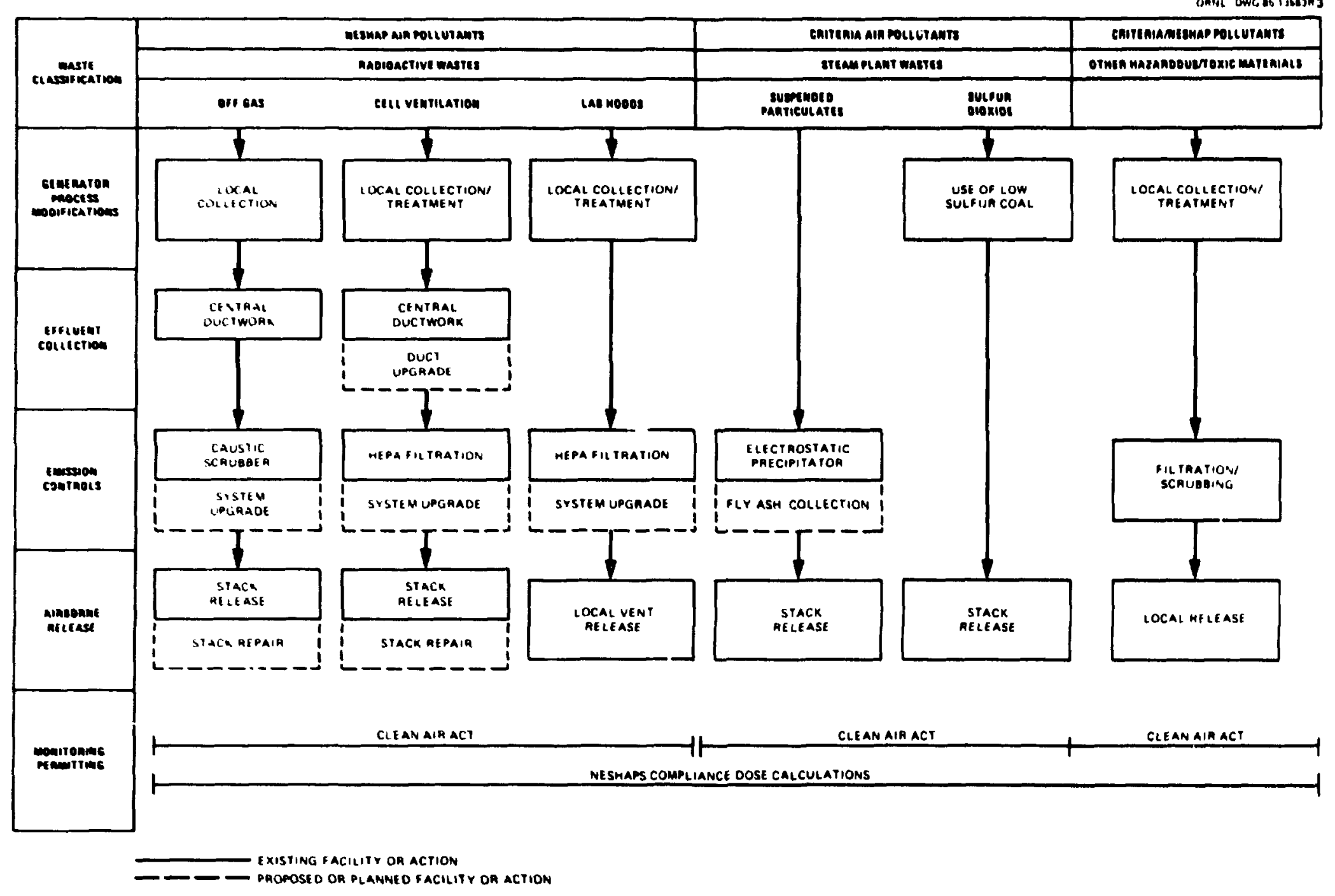

D2. 42 At polletion cantrol pregone etratiogs. 
air emission sourves began August 1985 for the facilities at ORNL and those operated by ORNL at the Y-12 Plant. In the first phase of the survey. the focation and description of 1860 sources were incorporated into a database for evaluation. A second phase of the survey was completed in Ju:y 1987 in order to better define sources not completely characterized in the first phase. The results of the stack and vent survey were reviewer' to determine if small emission sources that emit regulated pollutants require state air permits. As of December 31. 1987. ORNL had 56 active operating permits and 8 active construction permits. Air emission sources that have state air permits and those that have been identified as possible candidates for permits are being evaluated to determine if modifications, upgrades, or changes in operating requirements are needed to ensure th- the emissions will remain in compliance with applicable regulations. These emissions are aiso being evaluated to show that they do not constitute a health hazard to on-site personnel, the public, and the environment, and that they meet DOE ALARA 'bjectives.

Radioactive emission sources at ORNL can be divided into three general categories: (1) cell ventilation, which consists of high-volume, low-activity streams from enclosed areas such as containment or confinement areas (i.e., hot cells); (2) off-gas, which consists of low-volume, potentially high-activity gas streams from process vessels and from other areas where release of radioactivity is routine and of relatively high concentration; and (3) laboratory hoods and individual vents, which provide controlled ventilation for laboratory-type operations and normally vent at the source location. Airborne radioactive waste streams ai ORNL are generated either in the course of reactor operations and isotope and TRU element production or as a consequence of experimental laboratory and pilot plant programs. The streams consist primarily of particulates and gaseous radioisotopes of tritium. noble gases $\left({ }^{133} \mathrm{Xe}_{\mathrm{e}}\right.$ and $\left.{ }^{\mathrm{A}} \mathrm{Kr}\right)$, iodine, and radon. Methods for removal of particulates and gaseous radioisotopes fronı these streams depend on concentration and chemical state in the carrier gas. As a rule, it is easier to separate them before they become diluted with large quantities of air and mixed with other contaminants. Hence, ORNL policy is to decontaminate gaseous effluents, insofar as practical, at the source before they enter one of the plant ventilation systems. None of these systems include facilities for collecting and storing radioactive gases. Before the gases are discharged from any stack, the effluents are filtered through roughing and high-efficiency particulate air (HEPA) filters to remove particulate matter and, where conditions dictate, through charcoal absorbers or chemical scrubbers to remove reactive gases, such as halogens. In general, over $99.9 \%$ of the particulates and $95 \%$ of the reactive gases are removed before the gases reach the discharge point.

In 1986. gaseous emissions from ORNL facilities resulted in an estimated whole-body dose commitment of 0.5 mrem (about 2\% of NESHAP standards). Most of this dose resulted from the release of tritium from isotope production facilities at ORNL and smaller amounts from noble gases from isotope production and reactor and fuel processing operations. Studies are being performed to determine the cost benefit of further raductions in tritium releases by installing additional tritium removal equipment in the off-gas streams from these facilities. From a relative risk and cost benefit standpoint, it does not appear necessary to remove the noble gases from the gas streams currently except in cases in which there is a strong research or commercial incentive for recovery.

Other studies and inspections are being carried out to assess the condition of ventilation ducts, fans, filters. and other air emission control equipment associated with the main air-handling systems for radıoactive discharges. It is expected that, as a result of this work. implementation of capital projects in air pollution control will increase significantly during the next two to three years and 
then decline as the facilities are upgraded to provide long-term reliability and compliance with regulations.

Pollutant emissions from the ORNL steam plant are controlled by electrostatic precipitation of particulates and by the use of low-sulfur coal to control sulfur dioxide emissions. Hazardous or toxic releases from the Laboratory are controlled through process-specific collection and treatment systems using filtration or scrubbing to control effluents. All releases must be approved by the TDHE via the issuance of airborne effluent permits prior to construction of new processes or implementation of new procedures. Future strategies for air pollution control will continue the practice of treatment at the source, where possible.

The minimization of air-polluting emissions from ORNL operations is essential for compliance with regulutions. Air emissions will continue to be beld to ALARA levels by (I) upgrading air pollntion control equipment to improve control efficiency and equipment reliability, (2) incorporating process modifications which reduce the quantity or hazardous nature of emissions, and (3) continuing maintenance and inspection of all control equipment. Figure 4.3 illustrates the long-range schedule for upgrades of air pollution control programs at ORNL.

OANL.DWG 85-17426R 3

\begin{tabular}{|l|c|c|c|c|}
\hline $\begin{array}{c}\text { WASTE } \\
\text { CLASS }\end{array}$ & $\begin{array}{c}\text { GEMERATOA/ } \\
\text { PAOCESS } \\
\text { MODIFICATION }\end{array}$ & $\begin{array}{c}\text { EFFLUENT } \\
\text { COLLECTION }\end{array}$ & $\begin{array}{c}\text { EMISSION } \\
\text { CONTROLS }\end{array}$ & $\begin{array}{c}\text { AIREORME } \\
\text { RELEASE }\end{array}$ \\
\hline
\end{tabular}

\section{RADIOACTIVE WASTES}

OFF-GAS

CELL VENT

\begin{tabular}{|l|l|l|}
\hline FYB8-FY92 & FYB7-FY90 & FY $86-F Y 89$ \\
\hline
\end{tabular}

LAB HOOOS

FY81 FY90

STEAM PLAKT WASTES

SUSPENDED

PARTICULATES

FY 87 -FY 98

STACK ANO VENT SURVEY FYBG - FYBI

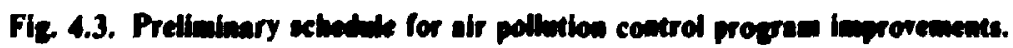




\section{WATER POLLUTION CONTROL PROGRAM}

Research, development, and operational activities at ORNL generate six wastewater streams (illustrated on Fig. 5.1). These include:

- LLLW, which originates from bot sinks and drains in RED laboratories and from processes such as the radiochemical pilot plants, nuclear reactors located in Bethel and Melton valleys, and the Process Waste Treatment Plant (PWTP).

- PW, which consists of liquid waste that is not normally radioactive but which may be contaminated periodically and all liguid waste that can contain small quantities of metals, anions, and organics.

- Wastes from area sources that are comprised of storm sewer collection from general use areas (such as buildings, roads, and parking areas), waste collected from contaminated areas such as the LLLW tank farms, and contaminated groundwater that is transferred to the liquid waste system.

- Point sources, which include coal yard runoff and discharges from cooling towers.

- Sanitary wastes, which consist of typical industrial sanitary sewage from Bethel and Melton valleys, where approximately 5200 people are employed.

- ORNL facilities at the Y-12 Plant, where wastewater is generated by diverse operations such as laboratory sinks, glassware washers, bottle-washing and soaking tanks, animal cage washers, and sterilizer condensate.

The objectives of the Water Pollution Control Program are

- to limit risks to employee health, the general public health, and the environment resulting from treatment and diecharge of liquid waste:

- to ensure that liquid discharges from ORNL facilities comply with applicable state and federal regulations and DOE Orders; and

- to ensure that stream operations are improved to minimize liquid waste generation and optimize liquid waste treatment.

The long-sange plan for each of the liquid waste categories is summarized below. A general plan for upgrading liquid waste systems at ORNL to meet water pollution control program objectives is illustrated by Figs. 5.2 and 5.3. A preliminary schedule for implementing the long-range plan is shown in Fig. 5.4.

Applicable state and federal acts, regulations, and standards are summarized as follows. 
OAML-OWO M0-PIIA

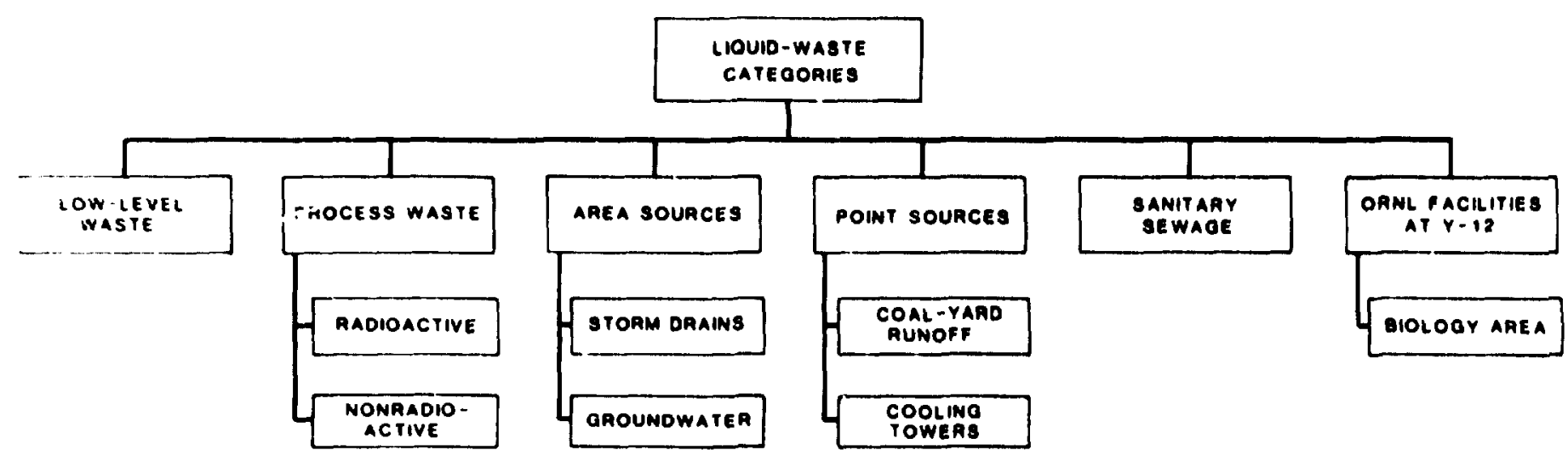

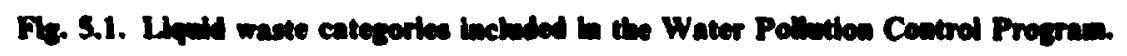


OAML OWO Be-p11n

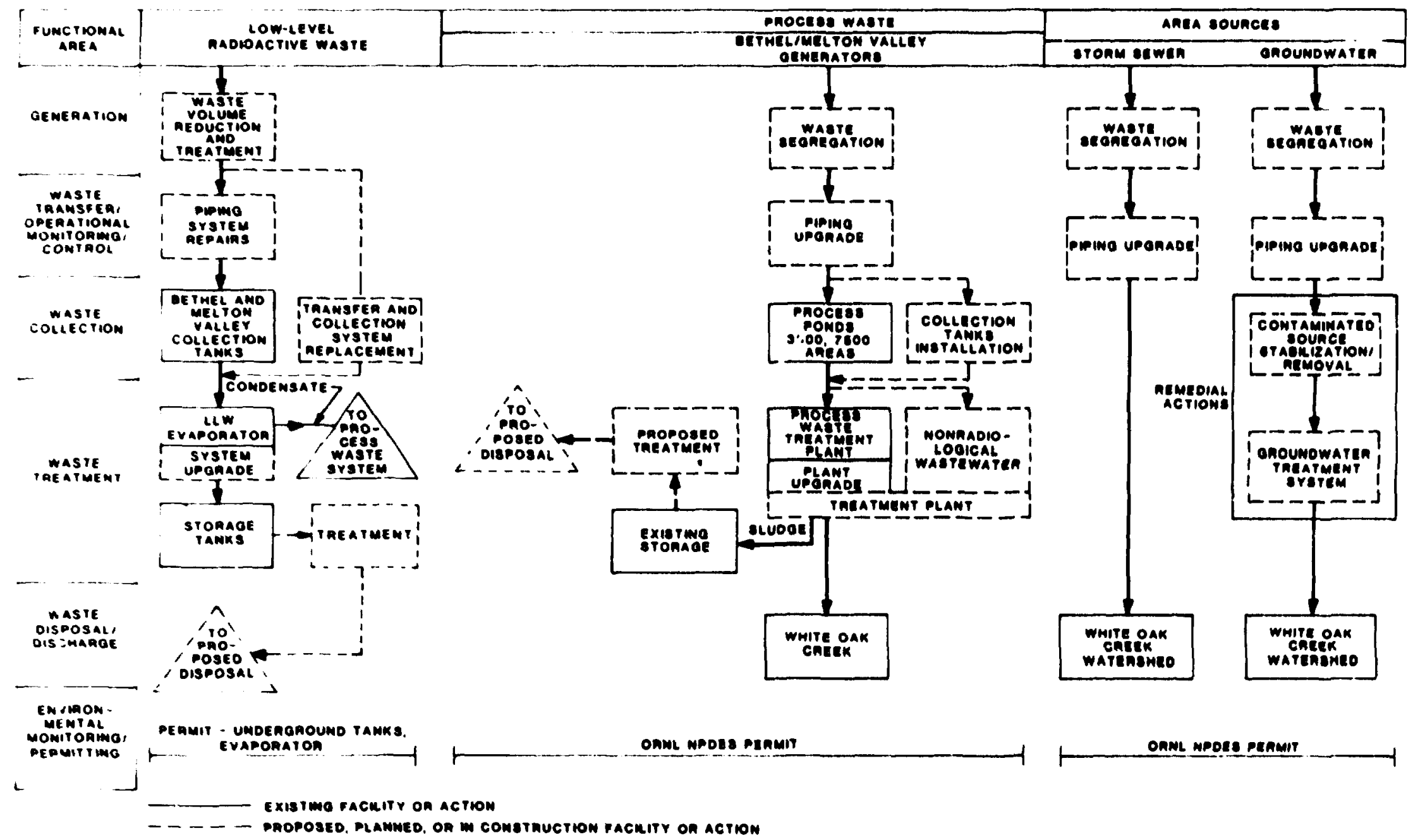

Fi. 5.2. Water polmedon control program exrategy-Part l. 


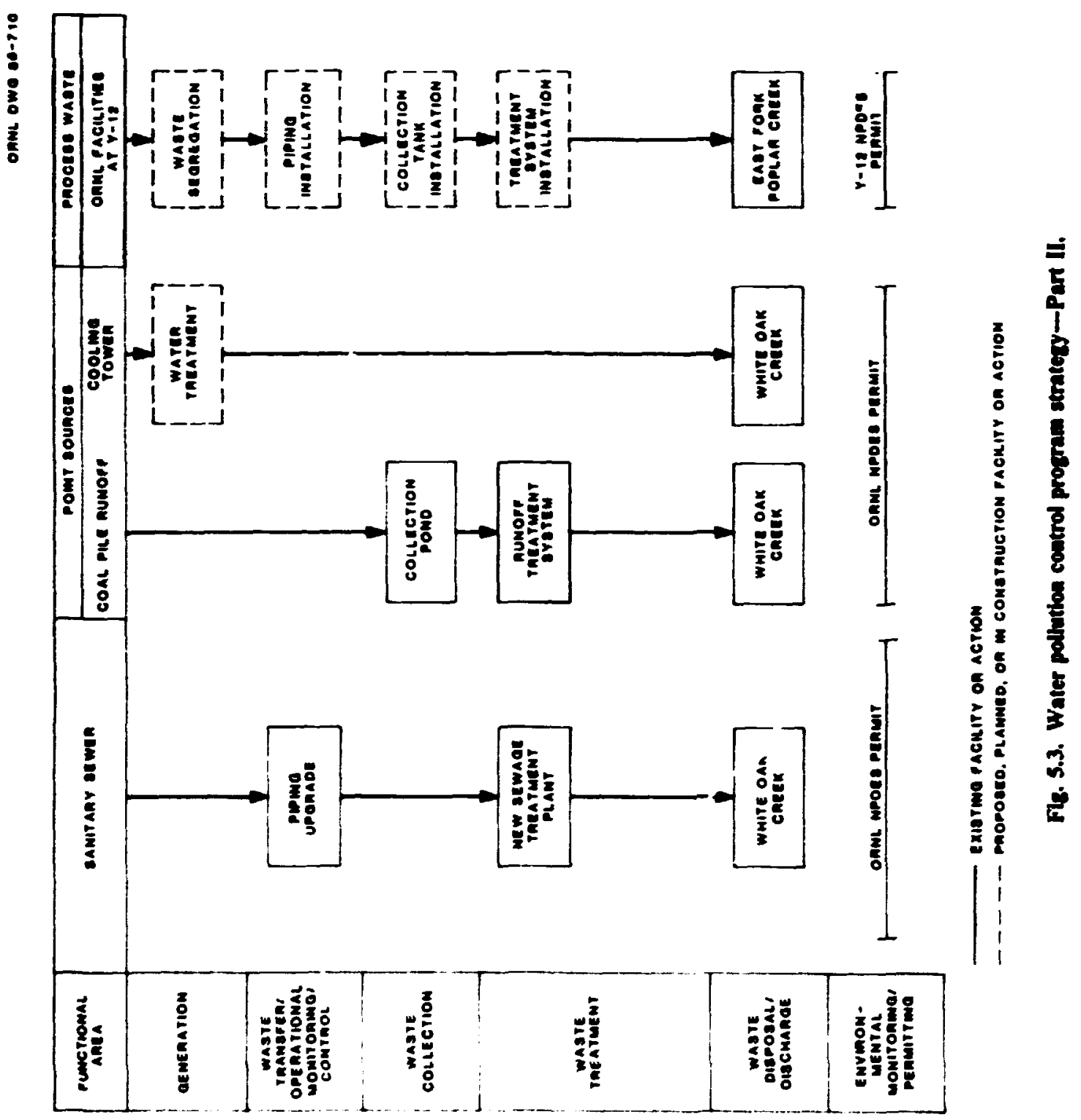


SHNL BWC: $461 / 425$

\begin{tabular}{|c|c|c|c|c|c|}
\hline $\begin{array}{c}\text { WASIE } \\
\text { C:ASS }\end{array}$ & $\begin{array}{c}\text { GEMERATOR/ } \\
\text { PROCESS } \\
\text { MOOIFICATIONS }\end{array}$ & $\begin{array}{c}\text { WASTE } \\
\text { IRANSFER }\end{array}$ & $\begin{array}{c}\text { WASTE } \\
\text { COLLECTION }\end{array}$ & $\begin{array}{c}\text { WASTE } \\
\text { TREATMENT }\end{array}$ & $\begin{array}{c}\text { INTERIM } \\
\text { STOAAGE }\end{array}$ \\
\hline
\end{tabular}

\section{PROCESS WASTE}

BETHEL NELIUN

(Alte)

\begin{tabular}{|l|l|l|l|l|l|}
\hline FYBE FYYI & FY86 F Y89 & FY8I FY89 & FY8G FY93 & FY86 TBD & FY,36 T8D \\
\hline
\end{tabular}

JHY AT 1 ?

\begin{tabular}{|l|l|l|l|}
\hline (YYB FY87 & FY86 FY87 & FY86 FY87 & FY86 FY89 \\
\hline
\end{tabular}

LOW LEVEL WASIE

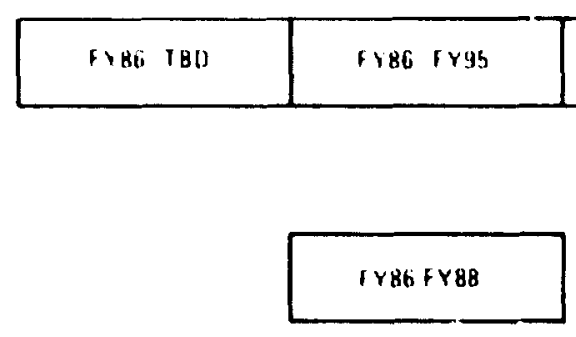

\begin{tabular}{l|l} 
FY8G FY95 & FYAG TBD
\end{tabular}

SAMITARY WASTE

POINT SOURCES

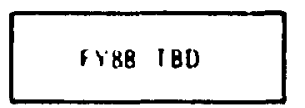

FY86 FY91

AAEA SOUACES

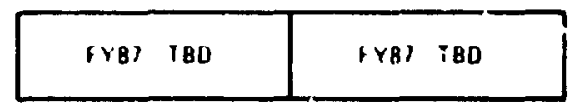

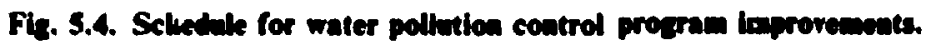




\section{Tenessee Laws and Reguhations}

The state of Tennessee has promulgated rules which establish standards of water quality. enforce RCRA regulations, classify surface water into seven categories of use, control underground injection of wastes, and protect groundwater.

\section{Federal Laws and Regalations}

Resource Cousermation aud Recowery Aet. RCRA governs the management of hazardous materials and underground storage tanks. The RCRA Subtitle C final rules for management of hazardous waste storage tanks were promulgated on July 14, 1986, and went into effect on January 12. 1987. This =g:iation does not alter the permit status of wastewater treatment tank systems. The final rule specifies secondary containment, materials compatibility with the wastes, corrosion protection, and leak detection for systems regulated under this rule. Maintaining compliance with RCRA significantly impacts the strategy for the LLLW system.

RCRA 3004(u) requires corrective actions for all releases of hazardous waste or hazardous constituents from any solid waste management unit at an RCRA facility. Corrective actions are required beyond the boundary of a facility where such action is necessary to protect human health and the environment. These requirements will be implemented at ORNL through RAP.

Clean Weser Act. The CWA regulates the discharge of nontoxic and toxic pollutants into surface waters. The state of Tennessee issued an NPDES permit to ORNL which became effective April 1, 1986. The permit includes a Federal Facility Compliance Agreement which delineates specific completion dates for system improvements. The permit designates categories of waste and outlines discharge requirements.

Safe Drinking Water Act. SDWA mandates establishment of uniform Federal standards for drinking water quality and sets up a system to regulate underground injections of wastes and other substances that could contaminate underground water sources.

\section{Departineat of Energy Ordens}

DOE is responsible for promulgating regulations, guidelines, and performance standards relative to certain aspects of the operations of DOE facilities. DOE has established orders and guides for the conduct of operations at contractor-operated sites which manage radioactive, hazardous, and mixed waste by setting a policy for compliance ivith public laws.

\section{LIQUID LOW-LEVEL RADIOACTIVE WASTE SYSTEM}

Risks to human health and the environment are being limited by implementing waste minimization programs and by implementing the BMP plan. ORNL recognizes that the hazards associated with handling LLLW are as great as hazards associated with handling formally classified hazardous wastes and applies RCRA requirements for systems handling hazardous waste to systems handling LLLW. The ORNL plan and strategy is to bring the LLW-collection and transfer (LL'N.CAT) system up to the management standards outlined in RCRA Subtitle C. Selected portions of the system have been removed from service or upgraded through G.'Ps to eliuninate leaks. The plan and strategy for continuing to achieve compliance with RCRA consists of actions that will ensure that the active LLLW system maintains compliance with applicable public laws. The actions include 
1. submitting a permit by rule application under RCRA;

2. complying with RCRA Subtitle C Part 266 when this regulation is promulgated;

3. interfacing with regulators while proceeding with plans to upgrade LLW-CAT systems;

4. replacing selected portions of the existing LLW-CAT systems with three LiPs-Bethel Valley LLW-CAT System Upgrade [FY 1988, $\$ 35$ million total estimated cost (TEC)], Isotopes Area LLW-CAT System Upgrade (FY 1991, 520 million TEC), and Melton Valley LLW-CAT System Upgrade (FY 1992, 520 million TEC).

5. adhering to RCRA $3004(u)$ requirements by conducting an RCRA Facility Assessment (RFA): and

6. adhering to RCRA 3004(u) requirements by conducting an RCRA Facility Investigation and Corrective Measures Study (RFI/CMS) since the results of step 5 were negative. (The RAP is responsible for the RFA and RFI/CMS.)

The waste minimization requirements of RCRA will be met by ORNL through the following activities:

1. charge-back of waste management costs to the waste generator,

2. implementation of the BMP plan, and

3. upgrading the waste tracking system to include generator compliance with waste acceptance criteria.

The state of Tennessee has been authorized to enforce RCRA regulations. The TDHE will be involved in all aspects of the plans and strategy described above.

The evolving Underground Injection Control (UIC) Regulations (Chap. 1200-4-6) of the Rules of the Water Quality Board for the State of Tennessee (first issued May 22, 1985) have been the basis for discontinuation of the operation of the hydrofracture process, which was used for solidification and disposal of LLLW from the mid-1960s until late 1984. Problems with the performance of the process and the disposal unit have also contributed to the discontinuance of this operation. Hydrofracture will not be used at ORNL and is no longer considered in the strategy and plans for disposal of LLLW concentrate.

Because the use of hydrofracture is no longer possible, an alternative means for disposing of LLLW concentrate must be implemented. There is currently limited storage capacity in LLW tanks, and a method for solidifying and disposing of LLLW is being developed to prevent the shutdown of the LLLW system. A liquid waste solidification demonstration is being planned for FY 1988. A limited quantity (about $50,000 \mathrm{gal}$ ) of waste currently stored in the Melton Valley storage tanks will be solidified by a cement-based process. The cost of this demonstration will be partially funded through the charge-back of waste handling costs to the generators. Significant research, development, and demonstration is needed to select and implement a long-term treatment option for LLLW. Disposition of solidified waste is being determined through the LLWNDD Program.

\section{PROCESS WASTE SYSTEM}

Guidelines for limiting environmental and public risk due to process waste system operation are established by the CWA and enforced through the NPDES permit. Implementing planned projects 
for constructing a new Nonradiological Wastewater Treatment Plant and upgrading the PWTP will bring the system into compliance with CWA requirements and limit rists to human health or the environment

The objectives of limiting employee risk will be met by using the results of ALARA studies of PWTP operations. Shielding requirements and operating procedures will be established based on the results of these studies.

The regulatory requirement which has had the most significant impact on process waste management has been the CWA. The ORNL NPDES permit became effective on April I, 1986, and includes the following requirements.

- Implementation of tne Federal Facility Compliance Agreement, which includes

- elimination of unmonitored and untreated discharges of pollutants to the watershed,

- elimination of the active use of surface impoundments, and

- construction of a Nonradiological Wastewater Treatment Plant (NRWTP).

- Efluent monitoring requirements include

- seven monitoring plans and

- efmuent requirements at specified process waste outfalls.

Capital projects, which should reduce discharges of pollutants to the watershed to acceptable levels, are being implemented. Planned and ongoing GPPs include:

Wastewater Piping Replacement

Wastewater/Storm Drain Isolation

Cobalt Removal System

Treatment for Anionic Species at the High-Flux Isotope Reactor (HFIR)

2000 Area Transfer Piping

Process Waste System Inflow/Infiltration

Upgrade Process Waste Collection System, 3000 Area

Melion Valley Process Waste Transfer Line Replacement

Volume Reduction Piping Modification, PWTP

These projects will segregate waste streams to appropriate treatment, reduce the volume of storm water and groundwater collected by the system, and install wastewater treatment at the source of contamination.

A definitive plan for collecting, treating, and discharging plant wastes in compliance with the CWA has been developed that employs the use of centralized treatment facilities located at strategic positions within ORNL.

The NRWTP will replace active surface impoundments with tanks and will provide for the collection and treatment of various major process wastewater streams from ORNL. A single NPDES discharge and montoring point will be maintained at the outfall and will include discharges from all ORNL PW systems.

Approximately $18.000 \mathrm{~m}^{3}$ per month $\left(4.7 \times 10^{6} \mathrm{gal}\right.$ per month) of process wastewater is treated for removal of radionuclides as required. The improved system will provide for the removal of suspended solids, heavy metals, and organics from this pretreated wastewater as well as $9600 \mathrm{~m}^{3}$ 
per month $\left(2.5 \times 10^{6} \mathrm{gal}\right.$ per month) of currently untreated wastewater. It has been designed to meet "best available technology" (BAT) guidelines, comply with regulatory efnuent requirements, and provide a continuous method of treatment. The final design is based on waste characterization data, treatability studies, and literature information.

A comprehensive investigation of the generation of PW containing nitrates has been completed, and a series of corrective measures have been implemented, including

- makeup water demineralizer replacement at the Oak Ridge Research Reactor,

- makeup water demineralizer replacement at HFIR.

- recovery of nitric acid at the Experimental Gas-Cooled Reactor, and

- upgrade of PWTP to reduce ion-exchange column regeneration, with a subsequent reduction in nitric acid use.

These actions have elininated discharges of nitrates and brought ORNL into compliance with NPDES requirements for reduction of nitrate loading on the watershed before the compliance date and at less cost than alternative plans and original estimates. Replacement of makeup water demineralizers was carried out in conjunction with the NR WTP.

The most significant activity required to improve PW stream operations is an upgrade of the PWTP. The primary driving force for upgrading the PWTP is to reduce waste volume through improved waste treatment. Prior to March 1986, the operation of the PWTP generated approximately $30 \%$ by volume and $80 \%$ by weight of all ORNL LLLW. Installation of a clarifier/precipitator and installation of temporary upgraded ion-exchange capacity has reduced the generation of LLLW significantly. To maintain and continue to improve the operation of the PWTP with regard to secondary waste stream generation, permanent equipment must be provided. Extensive pilot-plant research and development has been conducted to define the capital improvements. Shielding requirements and operating procedures will be established based on the results of ALARA studies. Solidification of the LLLW generated by operating the PWTP will be required as discussed in the section on LLLW.

\section{AREA SOURCES}

\section{Storm Sewer System}

Risks to human health and the environment will be limited by ensuring that discharges from the storm sewer system do not cause the receiving stream to exceed NPDES permit requirements, which include the Toxicity Control and Monitoring Plan (TCMP) and Biological Monitoring and Abatement Program (BMAP).

The requirement of the NPDES permit that is most significant to the storm sewer system specifies that there shall be no discharge of process wastewaters to the watershed that may have an adverse impact on human health or the environment. This requirement is tempered by the condition that process discharges will be allowed to continue to discharge into the receiving waters until the treatment facilities become operational, except where violations of water quality standards occur and can be abated through reasonable alternatives.

Characterization of process discharges to the watershed via the storm sewer system is being conducted, and capital projects that will eliminate process discharges have been initiated. The Water Pollution Control Program will prepare the Laboratory for compliance with proposed 
regulations and orders by following the policy of environmental ALARA. Discharges of radioactivity to the watershed through the storm sewet system will be incorporated into planning for contaminated groundwater control or eliminated at the source. Each storm sewer outfall that contains pollutants will be characterized to determine the source of contamination. Several capital projects are being implemented to line process piping known to be leaking and to route waste to the PW system.

Segregation of surface water and rainwater runoff from $\mathrm{PW}$ will reduce the volume of $\mathrm{PW}$ requiring treatment. Surface water and rainwater that does not require treatment will be discharged directly to the watershed; PW will be transferred to the appropriate treatment plant.

\section{Gremontwater}

Risks to human health and the environment will be limited by ensuring that pollutant discharges to the watershed by a groundwater pathway do not cause the receiving stream to exced NPDES permit requirements (which include the TCMP and BMAP). A pathways analysis will be conducted through the RFA and the RFI/CMS and will be used to assess the risk to the public from contaminated groundwater. An ORNL strategy for management of contaminated groundwater and surface water has been developed to evaluate and limit the rist to human health and the environment from groundwater contamination. The RAP is responsible for determining the extent of groundwater cleanup required by regulations.

If the risk to the public from current operations is acceptable, discontinuation of treatment of selected sources of contaminated groundwater will be proposed. The issue of whether the cost incurred by treatment of this water is the most environmentally beneficial way to spend available funds will have to be resolved. Currently, ORNL is spending about $\$ 2$ million annually to remove 1 Ci per month of "Sr from process wastewater.

If the risk to the public is unacceptable, contamination will be fixed at the source where possible. If public risk continues to be unasceptable after methods to prevent migration of contaminated groundwater off site have been implemented, groundwater collection and transfer (CAT) improvements will be evaluated, developed, and implemented. Options for segregating contaminated groundwater and surface water from clean groundwater and surface water and for collecting contaminated groundwater will be evaluated.

The state of Tennessee has drafted proposed regulations for groundwater and is seeking public comment." Discharges of radioactivity to the watershed by a groundwater pathway are regulated through the CWA and DOE Orders by adhering to the requirements of the NPDES permit. The Laboratory will prepare for compliance with proposed regulations and orders by following the policy of environmental ALARA. ORNL will be brought into compliance with the evolving state of Tennessee groundwater protection rules by developing and implementing a contaminated groundwater control strategy.

Segregation of contaminated groundwater from noncontaminated groundwater will reduce the volume requiring treatment. Groundwater that does not require treatment will be eliminated from the PW and LLLW systems by lining pipes and preventing in-leakage. Contaminated groundwater will be transferred to the appropriate treatment area.

-Tennessee Groundwater Maragement Strategy (Draft). Tennessee Department of Health and Environment. Division of Groundwater Protection. Nov. I6. 1987. 
The adequacy of the existing PWTP to treat wastes generated by increasing CAT of contaminated groundwater will be evaluated. New facilities may be required to treat groundwater.

\section{POINT SOURCES}

\section{Coal Yard Romoif}

A new treatment plant has been installed to treat the acidic runoff from the ORNL coal yard. The improved system provides controlled lime neutralization of runoff, sludge collection and dewatering. and discharge of the liquid eflluent to White Oak Creek (WOC). The coal yard treatment facility is monitored for compliance with NPDES permit limits.

The coal yard runoff treatment plant may be used for treatment of regenerate solutions from the steam plant boiler makeup water demineralizers. Treatability studies have been conducted and an Engineering Study and Estimate is under way. If the results show that treatment of the regenerant solution is cost-effective, this waste stream will be transferred to the coal yard runoff treatment plant. This action will result in more efficient use of the treatment system.

\section{Cooling Tower Dischares}

There are 26 operating cooling towers at the ORNL site. Buildings in Betbel and Melton valleys are serviced by 23 cooling towers; the ORNL nuclear reactors are serviced by 3 cooling towers. Chemical pollution associated with operation of all 26 cooling towers and potential radioactive pollution associated with operation of the 3 cooling towers that service reactors will be monitored according to NPDES requirements. Pollutants will be controlled through the Water Pollution Control Program by providing nontoxic treatment of cooling tower water and by establishing monitoring and control of radioactive pollutants.

\section{SANITARY WASTES}

Sanitary wastes from the Bethel and Melton valleys are treated at an upgraded sewage treatment plant. The effluent from the plant is monitored for compliance with NPDES permit requirements. The sanitary sewage collection system has also bren upgraded, and a reduction of $30 \%$ in excess sewage flow resulting from rain has been achieved.

\section{ORNL FACILITIES AT THE Y-12 PLANT}

ORNL facilities at the Y-12 Plant include portions of several ORNL dir isions (the Biology Division, Operations Division, Fusion Energy Division, and Engineering Technology Division) which are involved in activitier related to biological research, reactor development, controlled thermonuclear research, and stable isotopes separation. Wastes generated in these facilities are currently discharged directly to East Fork Poplar Creek and are subject to the Y-12 NPDES permit. The major ORNL activity at the Y.12 Plant involves providing treatment for the Biology Area PW streams. 


\section{SOLID WASTE MANAGEMENT PROGRAM}

An extensive program exists at ORNL for management of solid wastes. The objectives of the Solid Waste Management Program are to

- ensure that Solid Waste Management activities do not constitute a hazard to on-site personnel, the public, or the environment;

- ensure compliance with applicable federil, state, and local regulations; and

- ensure that solid waste management systems satisfy DOE ALARA objectives.

The laws and regulations that affect ORNL's Solid Waste Management Program include: DOE Order 5820.2. Radioactive Waste Management, and other DOE Orders; federal legislation such as RCRA, CWA, and others, as well as related EPA and state of Tennessee regulations.

Solid wastes, as addressed by this discussion, include a wide range of materials such as sludges, solidified or absorbed liquids, compressed gases, trash, construction debris, or other such materials, which are handled or disposed of in a solid or semisolid state. For planning purposes, snlid waste management has been divided into three broad categories (illustrated in Fig. 6.1).

Radioactive wastes include both LLW and TRU waste (Fig. 6.1). Hazardous waster include RCRA defined hazardous waste and mixed (both radioactive and hazardous) viaste. Conventional wastes include sanitary and process by-product wastes. These three categories can be broken down into several specific types of waste having more distinct and recognizable characteristics.

Radioactive solid waste materials are distinguished by the presence of radionuclides and can be separated into two basic types: TRU waste and nontransuranic or LLW. TRU waste is generally characterized by the presence of nuclides that are alpha emitters with long half-lives. TRU wastes contain nuclides that have atomic numbers greater than that for ${ }^{92} \mathrm{U}$ and have an activity level greater than $100 \mathrm{nCi} / \mathrm{g}$. LLW contains less than $100 \mathrm{nCi} / \mathrm{g}$ of TRU nuclides and typically contains nuclides with shon half-lives that are beta or gamma emitters.

TRU wastes are categorized as either contact-handled (CH-TRU) or remote-handled (RHTRU), based on the radiation level at the surface of the package. Those wastes exhibiting a surface dose rate of less than $200 \mathrm{mrem} / \mathrm{h}$ will be handled as $\mathrm{CH}$-TRU, whereas those wastes exhibiting a surface dose rate of greater than $200 \mathrm{mrem} / \mathrm{h}$ will be handled. RH-TRU.

Before 1970. TRU-contaminated solid material was not segregated from other low-level solid waste and was disposed of in shallow land burial in the ORNL SWSAs. Approximately $6200 \mathrm{~m}^{3}$ of ORNL buried waste is currently estimated to meet the definition of TRU. In some cases, trenches containing alpha wastes were capped with a layer of concrete; however, complete information about buried TRU waste is not available. As a result of this lack of segregation and information, closure of the burial grounds is being handled on a site-specific basis rather than a waste classification basis. Future actions related to the buried TRU will be encompassed by the ORNL RAP. 


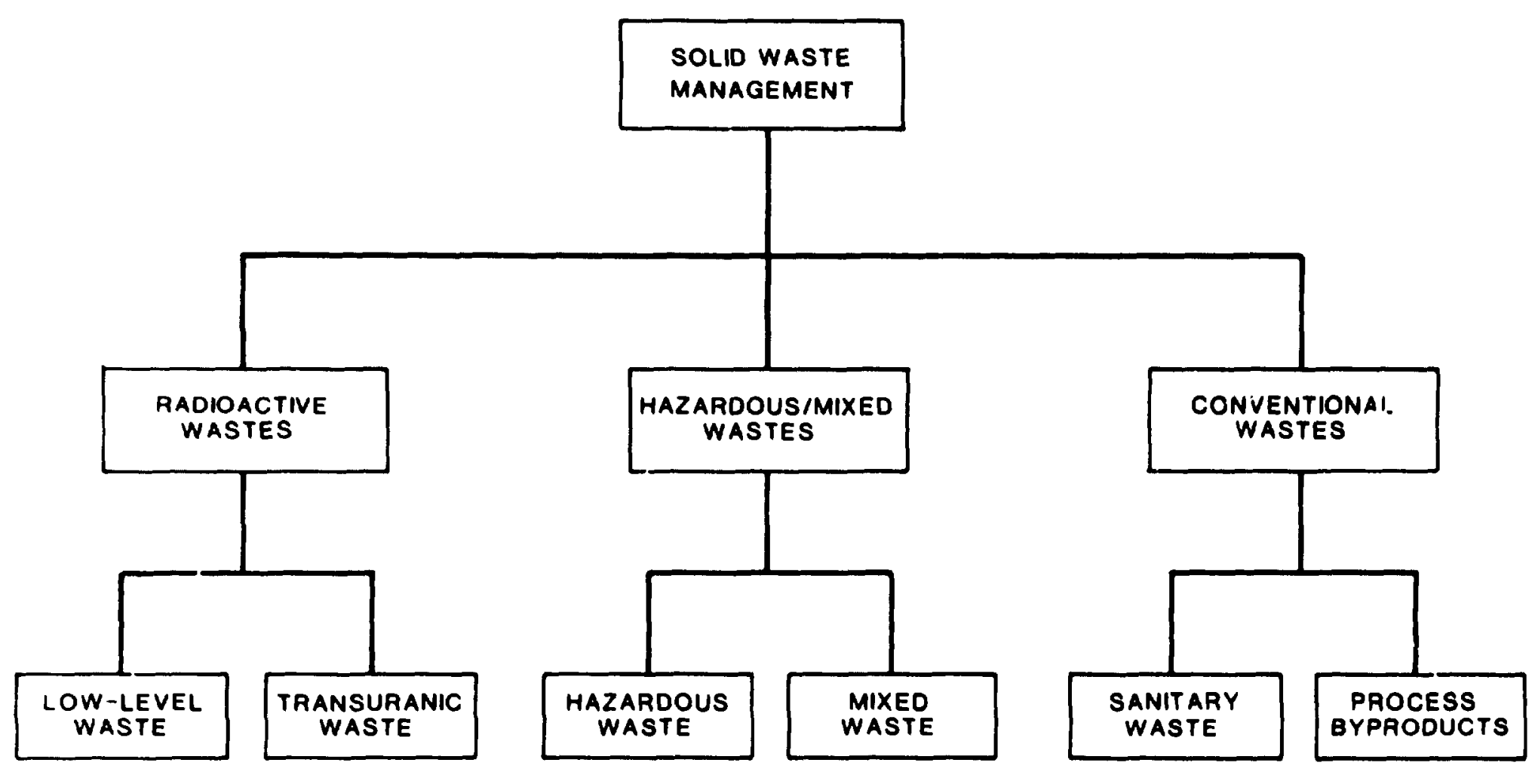

Fl. 6.1. General chasulitication of solld waste gemerated at ORNL. 
TRU waste management at ORNL is currently based on retrievable storage. No on-site method for permanent disposal of these wastes is available. The DOE Long-Range Master Plan for Defense Transuranic Weste has identified the WIPP (Waste Isolation Pilot Plant), a deep geologic repository in New Mexico, as the permanent disposal facility for TRU waste. Shipment of ORNL TRU waste to the WIPP is scheduled to begin in FY 1989.

The available retrievable waste storage for RH-TRU waste at ORNL is not adequate, and additional facilities for storage of concrete casks and TRU-contaminated waste packages, with high external gamma exposure, is needed. A GPP is planned for FY 1988 to fulfill this need. Sludges in the gunite storage tanks and the Melton Valley storage tanks were recently reclassified as RH-TRU waste. These sludges will have to be removed and fixed for permanent disposal. ORNL does not currently have the capability to process and package these sludges. A facility identified as the Waste Handling Pilot Plant (WHPP) is planned for the 1990s to fulfill this need. The WHPP facility will have the capability to package, assay, and certify TRU wastes.

Nontransuranic or LLW are those radioactive wastes that cannot be classified as transuranic waste. LLW is further categorized by the beta-gamma surface radiation intensity. If the intensity is equal to or greater than $200 \mathrm{mR} / \mathrm{h}$, the waste is classified as high-range (HR) waste. Below $200 \mathrm{mR} / \mathrm{h}$, the waste is designated as low-range (LR) waste. LR waste is further divided into compactible and noncompactible categories.

The current policy for LLW disposal on the ORNL site is to use shallow land burial with GCD techniques, such as underground concrete silos, auger holes, and concrete boxes in hillside and tumulus disposal units. GCD methods are used to reduce the potential for releases from new disposal operations to ALARA levels.

Disposal of LLW is currently accomplished at SWSA 6. The space remaining in SWSA 6 is limited to about 12 acres. Future disposal demonstrations and operations will become more and more restricted in size and scope to the point that, for all practical purposes, SWSA 6 will be closed to further disposal. The number of years of operation remaining for SWSA 6 is difficult to predict because of uncertainties in future waste generation rates, waste reduction efforts, waste volume reduction efficiencies, disposal efficiency of demonstrations, and utilization of ORGDP storage.

In the interim, the LLW strategy at ORNL is to reduce the volume of LLW going to SWSA 6 as much as possible to prolong the operating lifetime of the facility. Waste generation reduction efforts will continue to be pursued to minimize the volume of wastes requiring disposal. Volume reduction capabilities have expanded with the installation of a box compactor and iwo demonstrations of supercompaction techniques. Interim storage capabilities at ORGDP are being utilized for a significant fraction of the ORNL LLW material. The strategy also recognizes the potential for future reservation-wide disposal capacity resulting from the LLWDDD program.

ORNL is responsible for the development of an implementation plan for solid LLW consistent with the LLWDDD strategy which was used as a draft in July 1987. The preliminary implementation plan is scheduled for issue in January 1988. It will outline the activities, demonstrations, facilities, and associated schedules and costs required to implement the four-class LLWDDD system.

A waste is classificd as hazardous by EPA if it exhibits any of the characteristics of being corrosive, reactive, toxk, or ignitable as defined in 40 CFR 26I. A waste can also be classified as hazardous if it is included in the over 400 hazardous materials listed by EPA in 40 CFR 261. A hazardous material becomes a hazardous waste when it is discarded or is intended to be discarded. 
Any waste that is classified as hazardous by the EPA is subject to the cradle-to-grave manifest system: detailed records must be kept to track the waste from its origin to its ultimate disposal.

Mixed waste is LLW that also contains a hazardous waste component. Mixed LLW is being packaged and stored indefinitely until regulations are clarifred to allow its disposal by either inhouse or commercial facilities. Mixed wastes can be classified as being both hazandous and radioactive. A large amount of the research at ORNL is performed with radioactive materials. Therefore. generation of wastes that are both hazardous and radioactive is inevitable. The major types of mixed wastes at ORNL are radioactive oils and scintillation fluids. The radiation in these wastes is typically low level. but because the waste is mixed and no specific regulations apply, it is stored on site for an indefinite period of time.

ORNL has the capability to handle hazardous/mixed waste, but several of the existing facilities are interim or temporary. A Hazardous Waste Management Area (HWMA) has been constructed to facilitate the processing (packaging. storing. and shipment) of hazardous wastes for storage and disposal. The HWMA includes three facilities: the Chemical Waste Storage Facility (CWSF). Hazardous Waste Storage Facility (HWSF), and Long-Term Hazardous Waste Storage Facility (LTHWSF). The strategy for upgrading hazardous waste management at ORNL is to provide sufficient capability to track and handle the amounts and types of hazardous/mixed waste produced at ORNL. Included in this strategy is the ability to modify or expand those facilities as needed to adjust to changes in regulations and changes in operations.

Conventional solid wastes managed by ORNL include (1) construction debris. (2) ash from the ORNL steam plant. (3) filter cake from the coal yard runoff treatment system (which is disposed at the ORNL Contractor's Landfill), and (4) general refuse collected in trash cans and dumpsters around the site (which is disposed of at the Y-12 Sanitary Landfill).

The strategy for conventional waste is to phase out the use of the ORNL Contractor's Landfill during FY 1988 and direct all conventional waste disposal to the Y-12 Sanitary Landfill. Based on current plans, ORNL should not have any significant conventional waste disposal problems other than the additional cost of transport of waste to the $Y-12$ site and any increase in fees levied by Y-12 for waste disposal operations. However, there remains some possibility that ORNL may be subject to more stringent state permit requirements for the contractor's landfill, such as implementation of groundwater monitoring.

This strategy provides a mechanism for safe and environmentally acceptable handling of solid wastes generated at ORNL. In support of this strategy, significant facility improvements, procedural changes, and new facility development will be required. These activities are expected to take several years of dedicated suppon to meet the goals outlined. Ongoing investigations and planning will continue to identify changes and potential projects that will provide for more effective or more economical utilization of existing facilities. As a result of the investigation, new and better strategies will be developed for handling solid wastes. New improvements will be provided consistent with the changing regulatory environment and a continually expanded base of knowledge regarding waste generation, handling, and disposal. Preliminary schedule information for Solid Waste Management improvements is provided in Fig. 6.2 . 


\begin{tabular}{|c|c|c|c|c|c|c|c|}
\hline $\begin{array}{l}\text { WASTE } \\
\text { CLASS }\end{array}$ & $\begin{array}{l}\text { GENERATOR. } \\
\text { PRDCESS } \\
\text { MODIFICATIONS }\end{array}$ & $\begin{array}{l}\text { WASTE } \\
\text { IRANSPOAT }\end{array}$ & $\begin{array}{c}\text { WASTE } \\
\text { COLLECTION }\end{array}$ & $\begin{array}{c}\text { WASTE } \\
\text { TAEATMENT }\end{array}$ & $\begin{array}{l}\text { INTERIM } \\
\text { STORAGE }\end{array}$ & AECYCLE & $\begin{array}{c}\text { WASTE } \\
\text { DISPOSAL }\end{array}$ \\
\hline
\end{tabular}

RADIOACTIVE WASTES

?.

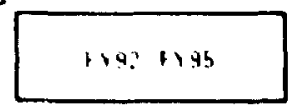

6 Y86 180

fY86 fY95

f Y 89780

an

FY8I fY90

F 90180

RCAA WASTES

MA: +ADJOS

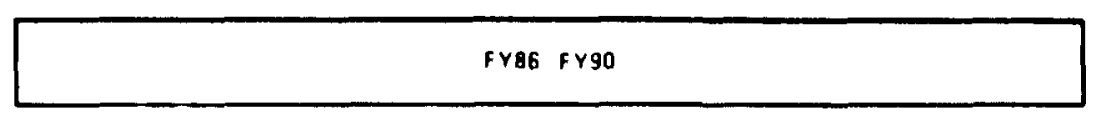

v: $: 0$

FY86 FY9?

FY92 180

\section{ISCA WASTES}

PCBTAANSEORMERS

FY86 FY8

hHTI JULS

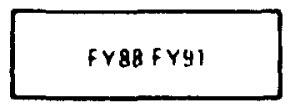

FY86 FY92

FY86 FY92

FY87 FY92

FY88 180

CONVENTIDNAL

NASTES

$9 Y 86 \quad 5 Y 93$

fY86 FYg3

FY88 FYgI

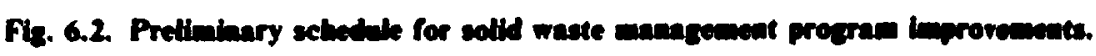




\section{REMEDIAL ACTION PROGRAM}

Past research, development, and waste management activities at ORNL have produced a significant number of surplus, inactive facilities contaminated with low-level radioactive and/or hazardous chemical wastes, as well as areas of off-site contamination. Such sites include SWSAs, waste ponds and seepage pits, radwaste processing and transfer facilities, research laboratories, dedicated environmental research areas, experimental reactors, radioisotope development facilities, the areas surrounding these sites, and off-site contamination in the Clinch-Tennessee rivers. Monitoring and control of these areas has been a continuing responsibility of the Laboratory to ensure that on-site personnel exposures and off-site releases are maintained within applicable DOE guidelines.

Over the past several years, significant environmental legislation has been enacted at both the state and federal levels in an attempt to provide appropriate controls over facility discharges and the cleanup of contaminated sites. The most important of these are the RCRA (including the 1984 Hazardous and Solid Waste Amendments). CERCLA (including SARA), the CWA, and the SDWA. In the near term, the RCRA and CWA regulations have had the greatest impact on the RAP through provisions of the RCRA and NPDES permits for ORNL. Under the 1984 Hazardous and Solid Waste Amendments, requirements have been (or are being) established for management and closure of facilities sontaining hazardous wastes. Of particular significance to the ORNL RAP are both specific requirements for landfills (e.g., affecting SWSA 6) and underground storage tanks and the more general requirements for assessment and corrective actions at sites found to be sources of continuing contaminant releases to the environment [RCRA Section 3004(u,v)]. In keeping with the DOE policy of controlling the potential hazards associated with operation of the ORNL facilities, site remedial actions will be conducted, where appropriate, to meet these requirements and to ensure adequate protection of on-site workers, the public, and the environment.

Implementation of the RAP at ORNL begins with identification of sites requiring corrective actions and will end with final certification of site closure or decommissioning activities. As outlined in Fig. 7.1, between these two milestones is a structured path of program planning, site characterizations, alternatives assessments, technology demonstrations, continued maintenance, and necessary interim corrective actions. Some of these activities will be accomplished over relatively short time frames (1-5 years), while others may extend for many years. The path that will be chosen for each site is dependent upon a number of variables, including site characteristics, regulatory requirements, and resource availability.

Depending upon the priority established for a given project after detailed assessment, one of two basic actions will be implemented: (1) remedial actions will be deferred and the facility will be placed into a monitored protective storage mode or (2) site closure or final decommissioning will be carried out to place each facility into a permanently stabilized condition requiring only periodic monitoring to verify site performance. The final long-term closure process will involve comprehensive planning to determine the overall strategy for remedial actions in the WOC 

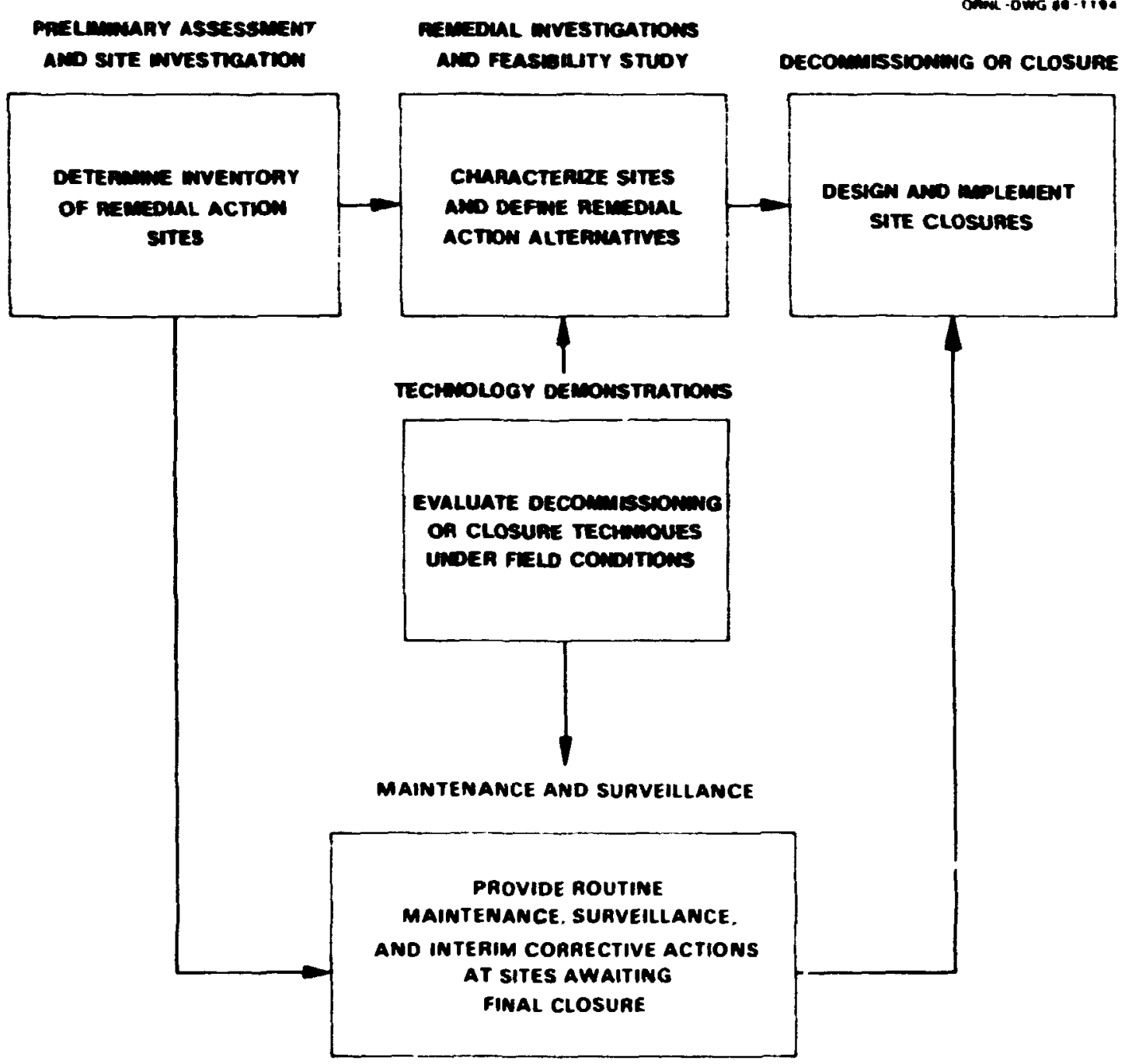

Fis. 7.1. Rewadial Action Progres inmineneatation flowetwart.

watershed and surrounding areas. As part of each of these actions, a variety of planning documents, characterization activities, technology evaluations, and design studies must be completed to make decisions concerning site disposition. Regulatory interfaces and approvals will be required at several steps within the process. Ultimately, all remedial action sites included in the ORNL inventory will pass through the decommissioning or closure phase to ensure long-term containment and disposal of residual radioactive or hazardous materials. The scheduing of decommissioning or closure, however, will depend upon project priorities established through regulatory interaction and approved funding levels.

The ORNL RAP currently includes some 164 identified sites in 13 basic categories. These sites, as summarized in Table 7.1, range in complexily from abandoned waste storage ponds and tanks to large experimental reactors and waste disposal sites. Some activity is under way at all of these sites. either through site characterization and assessment. poutine maintenance and surveillance. corrective actions. or facility decommissioning. Project priorities and funding allocations have been 
Telle 7.1. Renectiol action sites sumary

\begin{tabular}{lc}
\hline \multicolumn{1}{c}{ Category } & $\begin{array}{c}\text { Number } \\
\text { of sites }\end{array}$ \\
\hline Solid waste storage areas & 8 \\
LLW seepage pits & 8 \\
and trenctes & 14 \\
Process ponds & 14 \\
White Oat Creet Watershed & 35 \\
LLW line leak sites & 37 \\
Environmental research areas & 5 \\
Hazardous waste sites & 12 \\
Radioisotope proceasing facilities & 7 \\
Experimental reactor facilities & 17 \\
Radwaste facilities & 7 \\
Research laboratories & 4 \\
Inactive injection wells & 8 \\
Other contaminated sites & 164 \\
\hline
\end{tabular}

Established initially to provide continuing protective storage for all sites, to correct deficiencies in regulatory compliance, to reduce or eliminate known sources of environmental contamination, and to decontaminate facilities to allow beneficial reuse.

Site identification efforts have focused on completing a comprehensive inventory of hazardous and radioactive waste sites and a preliminary assessment of current site conditions. The latter (RCRA Facility) Assessment has been submitted to the EPA and TDHE with ORNL's recommendations for further steps necessary to comply with the RCRA Section 3004(u) corrective actions program. This site inventory will be updated as required to include facilities that have reached the end of their active life or additional sites that are identified through characterization activities. Preliminary characterization efforts are also under way to provide the baseline data necessary for project assessments and prioritization, as well as for future characterization planning. As part of the baseline data collection efforts, a groundwater monitoring network is being developed to allow for routine assessment of that critical environmental pathway.

To determine the need for, extent of, and priority of corrective actions at any of the remedial action sites, a comprehensive Remedial Investigations/Feasibility Study (RI/FS) program is being implemented. This Rl/FS effor, required under terms imposed by the ORNL RCRA permit, consists of site characterizations, assessments of decommissioning or closure alternatives for each site, and integration of proposed actions into a single feasibility study for the ORNL complex as a whole. These assessments are currently focusing on the concepts of in situ waste stabilization, onsite waste treatment and disposal, and decontamination of facilities for reuse where practicable. While the RI/FS activity is under way, the remedial action sites continue to be monitored and assessed through a comprehensive surveillance and maintenance program. Routine facility repairs, improvements, and monitoring are provided through this program to ensure containment of residual contaminants until site decommissioning or closure can be accomplished. Final decommissioning and closure of ORNL facilities will be accomplished according to regulatory approved plans that address the impacts to the environment from the range of remedial action alternatives. The timing for decommissioning closure activities will be established during the RI/FS sequence. High-priority 
sites will be addressed earlier, through near-term remedial actions; lower priority areas will continue to be maintained while awaiting final closure efforts.

In support of remedial action planning and implementation, significant efforts will be required in technology evaluations, corrective measures demonstrations, and performance criteria development. There has been only limited experience with performance of permanent site closure and decommissioning, especially on the large scale that will be required at ORNL. Because of this lack of proven technology, performance assessment of proposed corrective actions may be required in many instances prior to widespread application. Examples of such needed technology demonstrations and evaluations are in situ solidification of waste forms (sludges, soil, and solid wastes in trenches); permanent groundwater and surface water diversions; fixation of hazardous wastes for permanent disposal; and development of remotely operable equipment for waste removal and handling. Performance criteria will need to be established to direct the remedial action efforts, and pathways modeling will be required to allow for verification of long-term site stability. For the humid environment of the ORNL site, the control of surface and groundwater contact with any residual wastes appears to be the key component of long-term site performance.

Remedial action cost and schedule planning has been conducted for each of the major program phases described in Fig. 7.1. Because of (1) the preliminary nature of the site characterization data currently available, (2) the developing regulatory guidance on facility closure and site performance criteria, and (3) the lack of proven corrective action technologies in many cases, such planning must be viewed as preliminary in nature. A. more detailed information becomes available, the program costs and schedules will be refined and updated. As summarized in Fig. 7.2, the current program schedule provides for completion of the RI/FS effort in FY 1992. Based on decisions from that study, long-term decommissioning or closure for the remedial action sites will be conducted according to a regulatory approved schedule. The decommissioning or closure activities are anticipated to extend over a 10- to 20-year period. The current estimated resource requirements for comprehensive remedial actions at ORNL are over $\$ 1$ billion (unescalated), based on the straiegy of in situ waste stabilization where practicable. Significant increases in these estimates wou'd occur if extensive excavation and removal of wastes were required because of regulatory requirements.

As ORNL facilities continue to age and as the nature of R\&D activities and waste management practices change, it can be anticipated that additional facilities will require management under the RAP. When facilities reach the end of their useful lifetimes, comprehensive maintenance and surveillance will be needed to ensure continued containment of residual contamination. In addition, final decommissioning and closure will have to be provided through a dedicated program. Significant additions to the current RAP inventory of sites are expected over the lifetime of the Laboratory. 
PROGRAM PHASE

1. PRELIMINARY ASSESSMENT AND SITE INVESTIGATION

2. maintenamce and sufveillance

3. REMEDIAL INVESTIGATIONS AND FEASIBILITY STUDY

4. TECHNOLOGY DEMONSTRATIONS

5. SITE DECOMMISSIONING OR ClosuRE

METAL AEcoveAy fACILITY

FISSION PRODUCT DEVELOPMENT LABORATORY

otHer sites

6. REMEdLL ACtion PROGRAM SUPPOAT

\begin{tabular}{|c|c|c|c|c|c|c|c|}
\hline FY 86 & FY 87 & FY 8 & FY 80 & |FY 90 & FY O1 & | FY 92 & FY 92 \\
\hline
\end{tabular}

ROUTINE MAINTENANCE AND

SUAVEILLANCE ANO FACILITY UPGAADES

\begin{tabular}{ll}
\hline REMEOIAL INVESTIGATIONS ANO & FEASIBILITY \\
ALTERNATIVES ASSESSMEN TS & STUDY \\
\hline DECOMMISSIONINO OR & $\Delta$ \\
CLOSURE DEMONSTRATIONS & LONO-TERM \\
\hline
\end{tabular}

Fla. 7.2. Remedial Action Program Implementation eclwodule. 


\section{ENVIRONMENTAL MONITORING PROGRAM}

The primary role of environmental monitoring at ORNL is to ensure that Laboratory operations do not result in significant public bealth and environmental impacts and that operations are maintained in compliance with the applicable DOE Orders (5820.2 and 5480.4) and state and EPA regulations (CAA, CWA, RCRA, and CERCLA). As illustrated in Fig. 8.1, the environmental monitoring involves the surveillance of airborne emissions, surface water releases, and releases to the groundwater. Such monitoring is necessary for adequate control of waste management operations, as well as for assessment of impacts that these operations have on the environment surrousding the site. Air pollution monitoring includes routine source emisoion testing, ambient air monitoring, and air quality modeling. Monitoring of surface water discharges is primarily associated with compliance with the NPDES permit and involves routine effluent testing for specific parameters. Groundwater monitoring is to be performed to provide information for assessment of releases from area sources of contamination. A strategy for groundwater monitoring is being developed in conjunction with the RAP. Collection and assessment of data from all of these monitoring activities is currently provided through several on-site control centers, including the Waste Operations Control Center (WOCC), the Laboratory Shift Supervisor office, and the EMC Data Acquisition System (DAS). Construction is complete at the Laboratory Emergency Response Center (LERC), the site of a comprehensive Laboratory emergency control center (Building 4512). This facility provides 24-hour backup monitoring capability for the WOCC and will also contain an operator's terminal for the EC\&HP environmental monitoring system. The LERC will be capable of assuming command of the WOCC if this should become necessary. However, its primary role in the EC\&HP environmental monitoring system will be to initiate off-shift response in the event of a system malfunction or contaminant release alarm sounded by the operator's terminal.

To ensure continued protection of the environment and the health and safety of workers and the public and to achieve compliance with requirements for environmental monitoring, significant upgrades at existing ORNL facilities must be provided. Such improvements will be required in two areas of surveillance ( airborne and surface water) and are expected to be carried out over the next several years in accordance with the preliminary schedule outlined in Fig. 8.2

in the area of airborne emission controls, the first phase of the Environmental Monitoring System Upgrade (EMSU) project completed station construction and installation of the monitoring/sampling instrumentation at ORNL. The requirements placed on the contractor were developed via the capital equipment upgrade of the Perimeter Air Monitoring (PAM) system. Through this upgrade, experience was obtained on the capabilities of real-time monitoring/sampling equipment and data acquisition that enabled a detailed specifications document to meet the needs of ORNL. This specifications document included sensitivities for radiological measurements made from both stack discharges and the ambient air and data reporting via trend analysis, error messages, and alarm setpoints. A second phase of monitoring system upgrades is planned for FY 1988 and FY 1989 to complete upgrading of the system. 


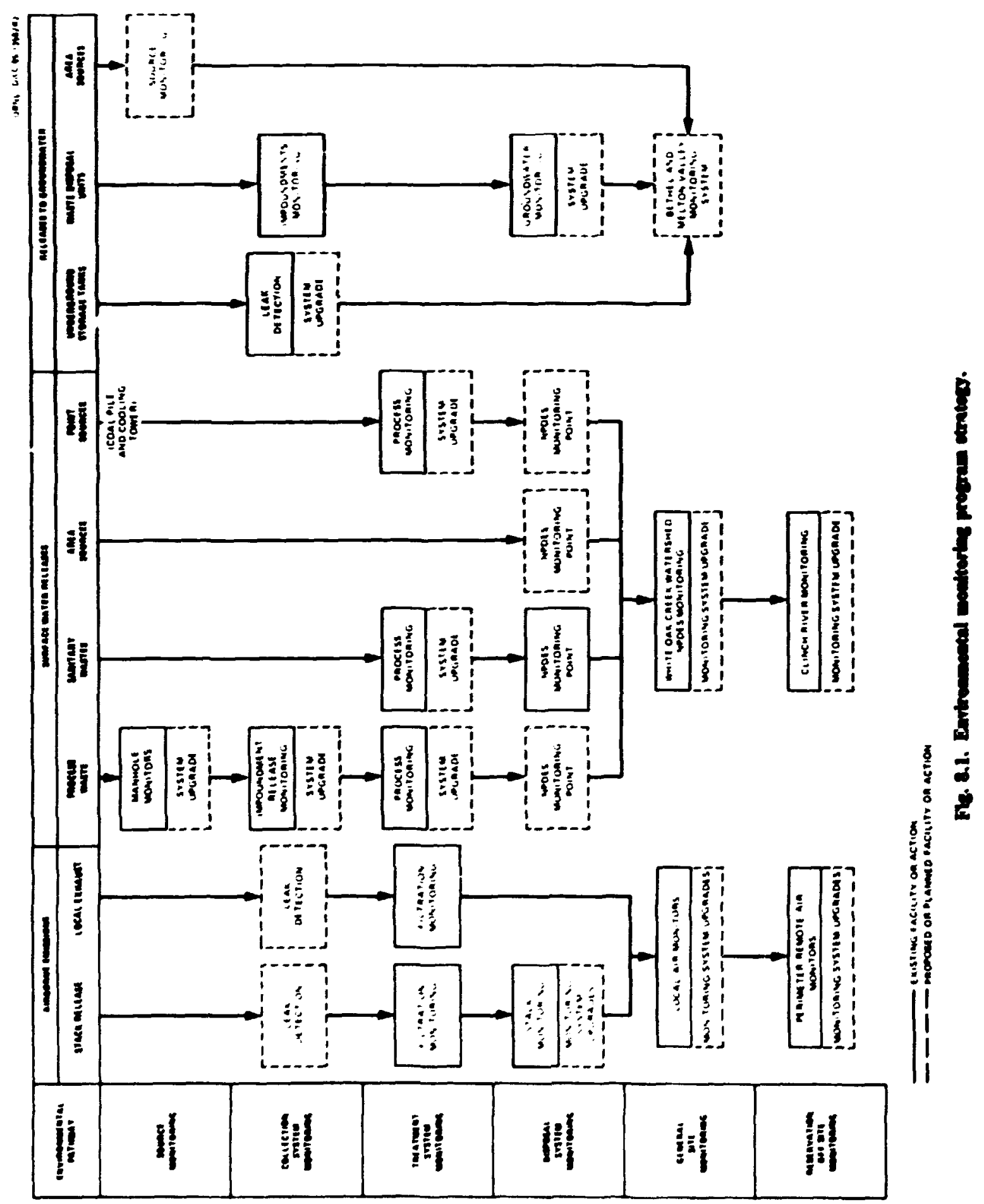


ORNL DWG 85 17A58R

\begin{tabular}{|c|c|c|c|c|c|c|}
\hline $\begin{array}{l}\text { ENVIRONMENTAL } \\
\text { PATHWAY }\end{array}$ & $\begin{array}{l}\text { SOURCE } \\
\text { MONITOAING }\end{array}$ & $\begin{array}{l}\text { COLLECTION } \\
\text { SYSTEM } \\
\text { MONITORING }\end{array}$ & $\begin{array}{l}\text { TAEATMENT } \\
\text { SYSTEM } \\
\text { MONITORING }\end{array}$ & $\begin{array}{l}\text { OISPOSAL } \\
\text { SYSTEM } \\
\text { MONITOAING }\end{array}$ & $\begin{array}{l}\text { GENERAL } \\
\text { SITE } \\
\text { MONITORINO }\end{array}$ & $\begin{array}{c}\text { AESEAVATION } \\
\text { OFF.SITE } \\
\text { MONITOAING }\end{array}$ \\
\hline
\end{tabular}

AIRGORNE

FY86-FY94

\begin{tabular}{|l|l|l|}
\hline FY86-FYg2 & FY86-FY93 & FY86-FY90 \\
\hline
\end{tabular}

SURFACE

WATER

RELEASES

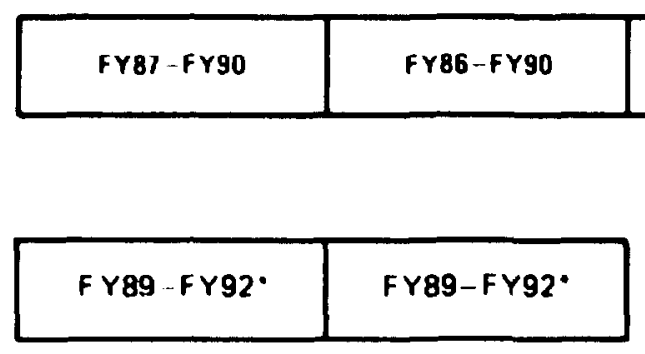

FY86-FY92

FY86-FY90

FY86-FY90

FY 86-FY 90

\begin{tabular}{|c|c|c|c|c|}
\hline $\begin{array}{c}\text { RELEASES } \\
\text { TO } \\
\text { GROUNDWATER }\end{array}$ & F Y 89 FY92' & FY89-FY92* & FY89-FY92 & FY $89-F Y 82^{\circ}$ \\
\hline
\end{tabular}

-SPECiFIC UPGRADE actions WILl DEFEND ON INTEGRATION OF THE ENVIRONMENTAL MONITORING AND REMEDIAL ACTIONS STRATEGY AND PLANS FOR GROUNOWATER MONITORING

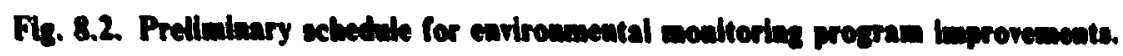


In the area of NPDES surface water monitoring, there are currently 13 compliance (point source or ambient) outfalls. These are listed in Table 8.I. The NPDES permit also includes effluent limitations for the NRWTP which is scheduled for comptetion in 1989. It is doubtful that the new point source outfalls will be added to the permit because the NRWTP will have the capacity to treat additional PW streams. However, additional monitoring requirements (which are currently monitored via grab samples) should be considered for other categorical outfalls delineated in the permit.

Groundwater monitoring system improvements must address the regulatory requirements outlined as part of RCRA and CERCLA. However, an assessment of these regulations and their requirements for groundwater monitoring at the ORNL perimeter has not been completed. When the assessment is finished, a strategy for perimeter groundwater monitoring will be developed. Many. if not all, of the groundwater quality wells that will be necessary for routine groundwater quality monitoring will likely have been installed as part of the site characterization activities within the RAP. A total of 332 piezometer wells have been completed by the RAP and are being utilized for data acquisition. About 100 groundwater quality wells have been installed by the RAP, and it is anticipated that several hundred additional groundwater quality wells will be required at ORNL to characterize and monitor facilities in accordance with environmental regulations. Although the current and future groundwater quality wells are being implemented by the RAP as part of the site characterization activities, some of the groundwater quality wells will be used on a longer-term basis subsequently for routine compliance monitoring.

Talke 8.1. NPDES compliance oxdilits

\begin{tabular}{|c|c|}
\hline Onafall/Point Somse & Rey,irenew \\
\hline $\begin{array}{l}\text { Sewage Treatment Plant } \\
\text { Coal Yard Runoff Treatment Facility } \\
\text { I500 Area } \\
2000 \text { Area } \\
190 \text { Ponds } \\
\text { Process Waste Treatment Plant } \\
\text { TRU/TURF Process Waste Basins } \\
\text { HFIR Process Waste Basins } \\
\text { ORR Resin Regeneration Facility } \\
\text { 3518 Acid Neutralization Facility }\end{array}$ & $\begin{array}{l}\text { effuent limitations } \\
\text { effuent limitations } \\
\text { monitoring only } \\
\text { monitoring only } \\
\text { monitoring only } \\
\text { monitoring only } \\
\text { monitoring only } \\
\text { monitoring only } \\
\text { monitoring only } \\
\text { monitoring only }\end{array}$ \\
\hline \multicolumn{2}{|l|}{ Oufall/Aminent } \\
\hline $\begin{array}{l}\text { Melton Branch Weir } \\
\text { White Oak Creek Weir } \\
\text { White Oak Dam Weir }\end{array}$ & \\
\hline
\end{tabular}




\section{PROGRAM BUDGET SUMMARY}

Based on the Program strategy outlined in the previous chapters of this ORNL Long-Range Environmental and Waste Management Plan, preliminary cost estimates have been developed for completion of the comprehensive environmental restoration and facilities upgrade activities at ORNL. As shown in Table 9.I, significant resource allocations will have to be made by DOE in each of the major program categories (solid, liquid, gas, environmental monitoring, and remedial actions) to ensure safe operation of the waste management systems and to provide for corrective actions at contaminated sites. The TECs have been included to provide a picture of the anticipated out-year requirements. Estimates have been made of both the expense and capital resource commitments that are needed to adequately support implementation of the restoration efforts. As currently outlined, this commitment is expected to exceed \$I.S billion (in current-year dollars) over the lifetime of the effort.

The cost and schedule estimates presented in this preliminary plan are based on adherence to current regulatory and legal requirements. Compliance schedules that are only now being developed cas be expected to significantly impact the planning and implementation of the proposed facilities upgrade and environmental restoration activities. As changes occur in current regulations or in the way in which these regulations are applied to DOE sites like ORNL, similar revisions would be expected in the program scope and schedules. In addition, the current cost estimates are based on preliminary and often incomplete characterization and ascessment data and on action plans that have not received regulatory approval. Hence, these scoping estimates need to be vieved as projecting order-of-magnitude values only. As regulatory requirements are better defined and project plans are further developed, these estimates will be refined.

As highlighted in Fig. 9.1, significant resources will have to be allocated over the next few years in the initial phase of the environmental restoration effort. Expense funding support needs are

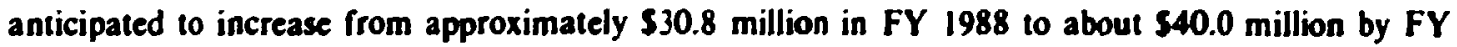
1994. The greatest portion of this increase will be associated with implementation of the comprehensive site RAP. Capital fund requests are also expected to increase during these years, from approximately $\mathbf{2 0 . 0}$ million in FY 1988 to $\mathbf{\$ 5 8 . 2}$ million in FY 1994. Two line item projects (WHPP and LLW-CAT) make up the major portion of that increase, although significant growth in both the GPP and general purpose equipment (GPE) budgets is also anticipated. Some reallocation of the expense funding requests to capital requests can be expected to occur in the outyears, once sufficient remedial action planning has been completed to allow for capital projects identification.

The current planning budget is based on the continued support of restoration and upgrade activities primarily through two major DOE programs, Defense and Energy Research Programs. Clear division of responsibilities between these two organizations and the coordination of the multiprogram effort are critical. Resolution of the long-term roles of these two DOE programs in the restoration activities has been achieved which will allow the comprehensive program budget 


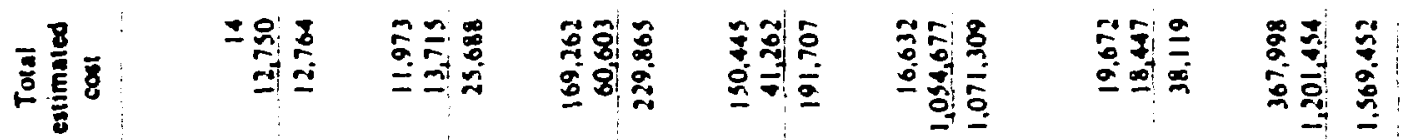

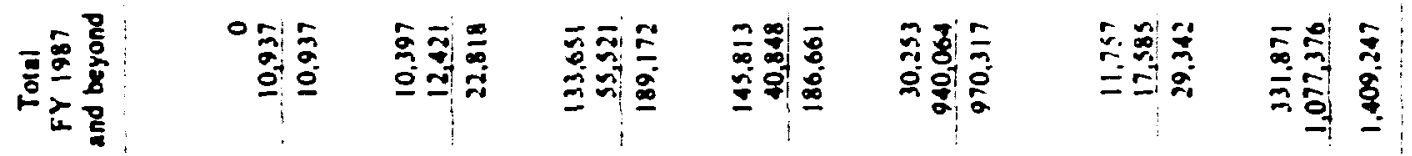
总

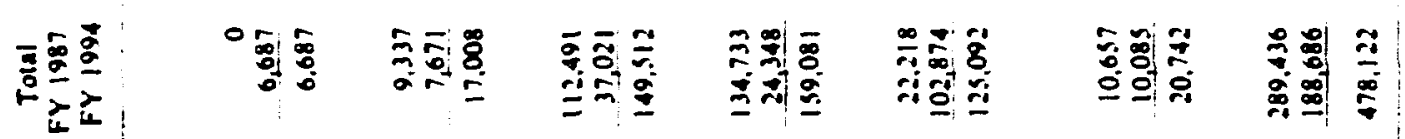

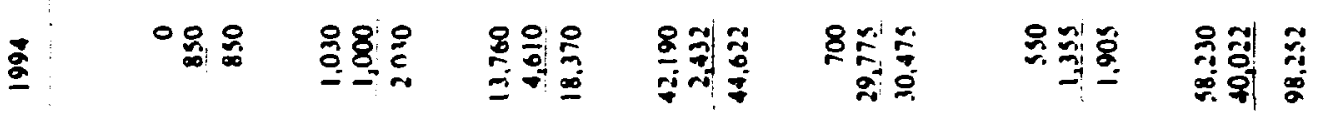

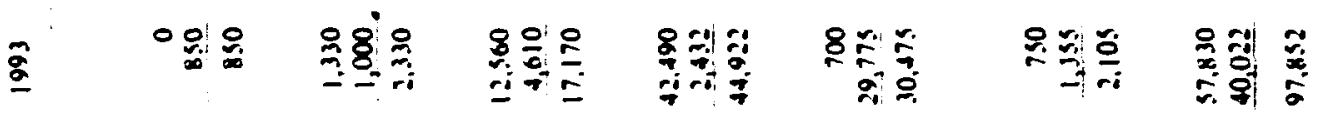

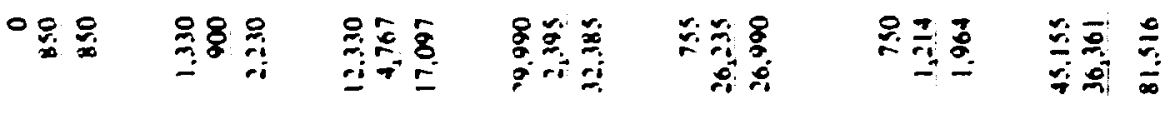

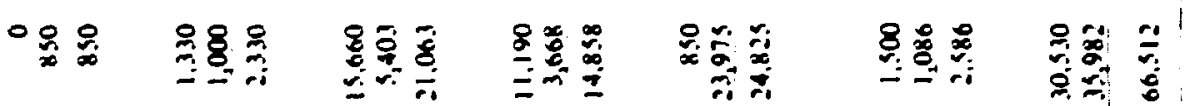

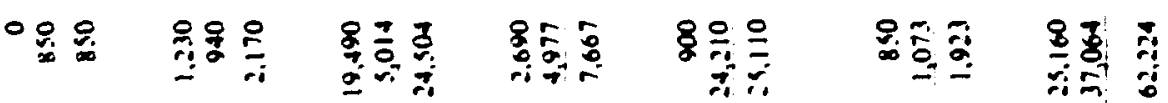

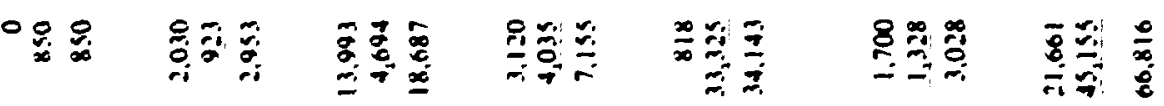

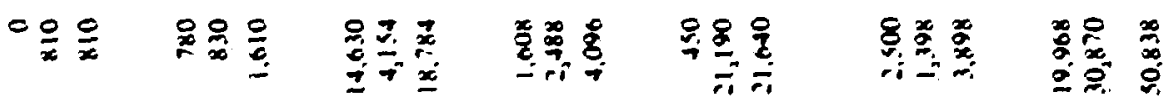

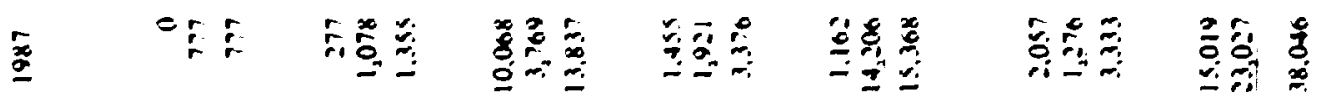

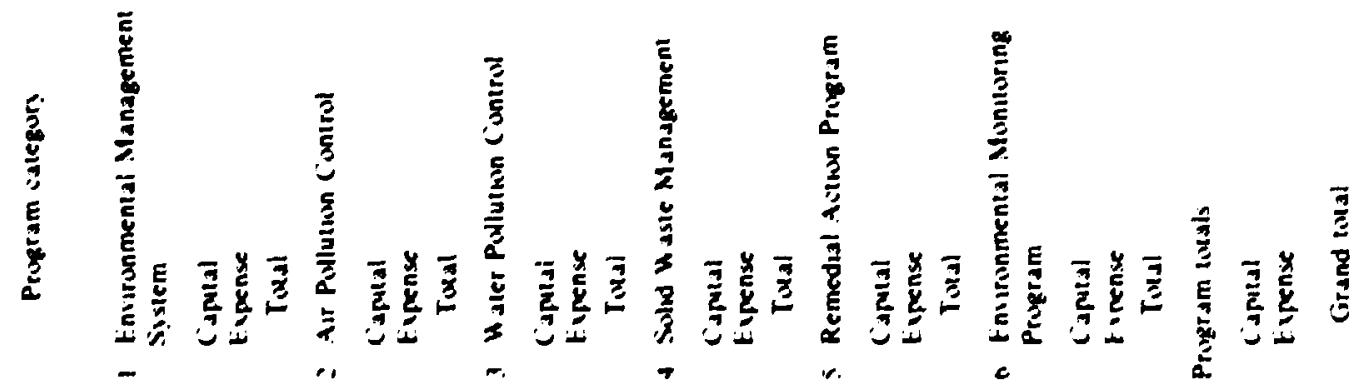




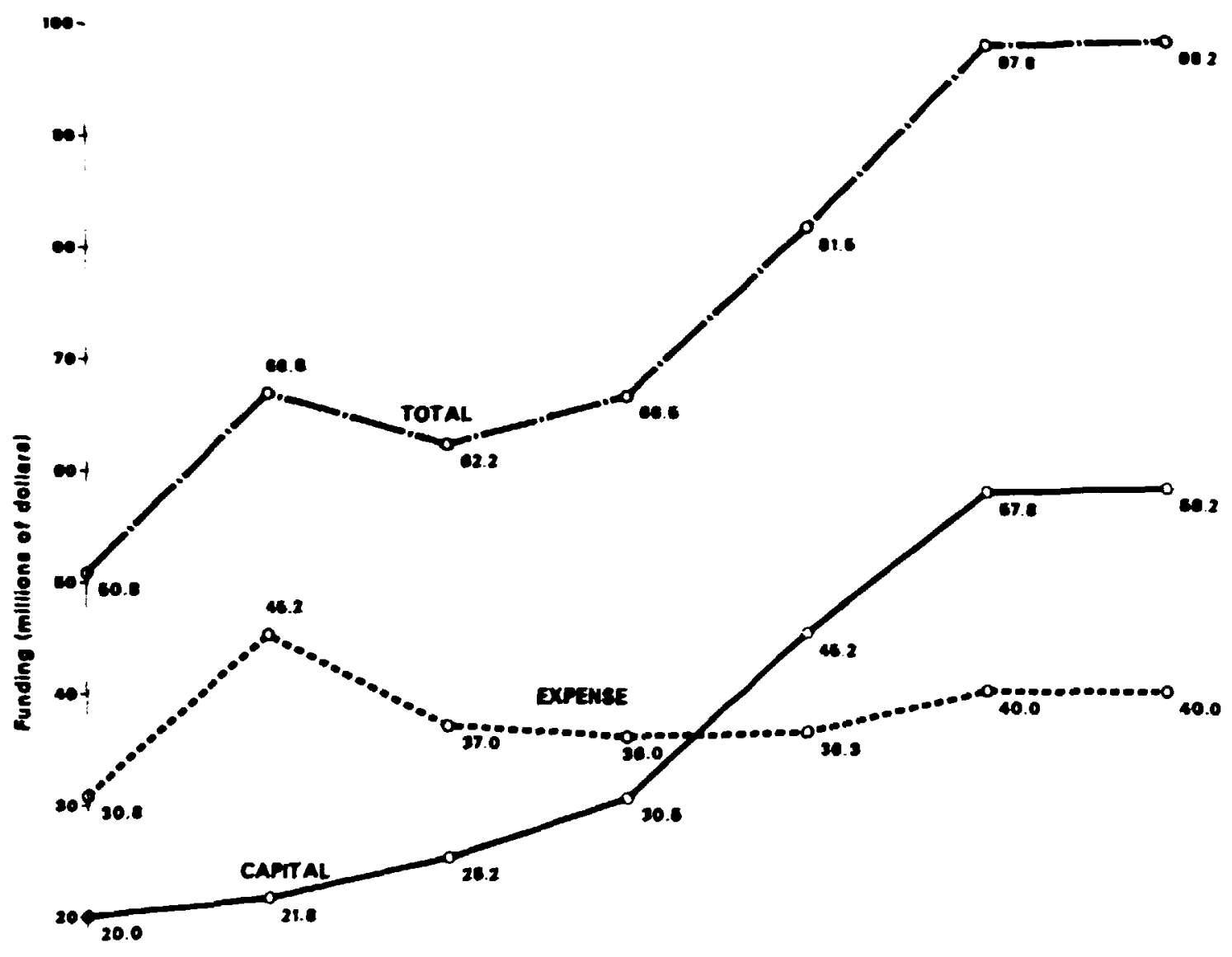

$10+$

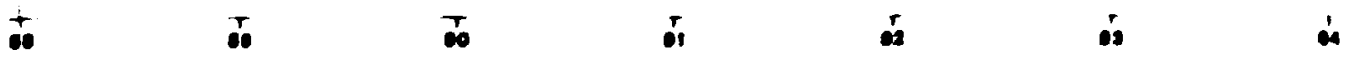

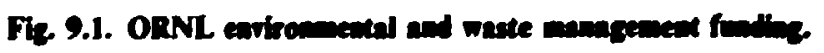

planning needed during the next few years. Another important budget consideration that will be under development in the coming years is the incorporation of long-term facility operating costs and increased environmental monitoring costs into ORNL planning. Significant increases in these costs can be expected as new facilities come on line and as treatment and monitoring requirements become more strict. As part of the present planning activities, estimates of these costs have been developed and presented for ORNL management consideration in Tables 1.2 and 1.3. Further development of these estimates will be included in future updates of this Plan.

Table 9.2 shows the environmental cross-cut budget estimates for FY 1987 through FY 1989. The base program is a sum of the funding for routine operations and the LLWDDD core program (Table 1.4) and the expense funding from WBS I, ORNL Comprehensive Environmental management. The non base program funding shown within the cross-cut budget is the remaining programmatic Environmental and Waste Management funding (Table 1.1) which has been distributed through the DOE regulatory areas. 


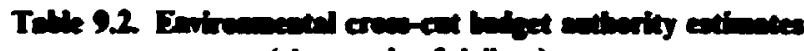
(thousands of dollars)

\begin{tabular}{|c|c|c|c|}
\hline & FY 1987 & FY 1988 & FY 1989 \\
\hline \multicolumn{4}{|l|}{ Oranding } \\
\hline \multicolumn{4}{|l|}{ Envircameatal } \\
\hline Bese program & 19,232 & 21.191 & 24,214 \\
\hline CAA & 1,078 & 830 & 923 \\
\hline CWA & 3,769 & 4,154 & 4,694 \\
\hline RCRA & 17,403 & 25,076 & 39,038 \\
\hline Tocel & 41,482 & 51.251 & 68.869 \\
\hline \multicolumn{4}{|l|}{ 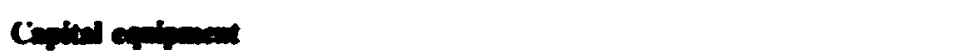 } \\
\hline \multicolumn{4}{|l|}{ Eavirommental } \\
\hline Base program & 35 & 300 & 44 \\
\hline $\mathrm{CAA}$ & 177 & 30 & 30 \\
\hline CWA & 493 & 280 & 80 \\
\hline RCRA & 1,349 & 1,203 & 1,038 \\
\hline Total & 2,054 & 1.813 & 1.592 \\
\hline \multicolumn{4}{|c|}{ 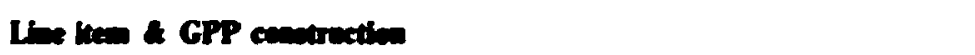 } \\
\hline \multicolumn{4}{|c|}{ Enviroamental } \\
\hline CAA & 100 & 1,700 & 3,000 \\
\hline$C W A$ & 10.120 & 9.550 & 1,663 \\
\hline TSCA & 33 & & \\
\hline RCRA & 2,747 & 7,205 & 14,850 \\
\hline Orher & & & 650 \\
\hline Total & 13,000 & 18,455 & 20,163 \\
\hline \multicolumn{4}{|l|}{ Tetals } \\
\hline \multicolumn{4}{|l|}{ Environmental } \\
\hline Base program & 19,267 & 21,491 & 24,658 \\
\hline CAM & 1,355 & 2,560 & 3,953 \\
\hline CWA & 14,382 & 13,984 & 6,437 \\
\hline TSCA & 33 & & \\
\hline RCRA & 21.499 & 33,484 & 54.926 \\
\hline Oiher & & & 650 \\
\hline Total & 56,536 & 71,519 & 90,624 \\
\hline
\end{tabular}




\section{INTLRNAL DISTRIBUTION}

I. E. D. Aebischer

2. T. D. Anderson

3. S. I. Auerbach

4. J. S. Baldwin

5. J. B. Ball

6. J. A. Barker

7. L. D. Bates

8. J. M. Begovich

9. J. B. Berry

10. W. J. Boegly

11. H. M. Braunstein

12. C. H. Brown

13. W. D. Burch

14. G. H. Burger

15. T. W. Burwinkle

16. H. M. Butler, Jr.

17. G. E. Butterworth

18. T. R. Butz

19. R. M. Canon

20. K. W. Cook

21. L. S. Corrill

22. A. G. Croff

23. N. H. Cutshall

24. J. N. Dumont

25. S. P. du Mont III

26. N. W. Durfee

27. B. G. Eads

28. B. M. Eisenhower

29. L. D. Eyman

30. C. L. Fox

31. P. J. Franco

32. W. Fulkerson

33. H. R. Gaddis

34. A. S. Garrett. Jr.

35. C. W. Gehrs

36. A. H. Geisler

37. R. K. Genung

38. R. W. Glass

39. R. A. Griesemer

40. J. D. Griffin

41. R. E. Helms
42-46. L. G. Hill

47. D. D. Huff

48. L. D. Hyde

49-50. C. G. Jones

51. E. C. Jones

52. M. L. Jones

53. S. V. Kaye

54. J. L. Keller

55-59. C. M. Kendrick

60. D. B. Kendrick

61. J. M. Kenuerly

62. R. H. Kingrea

63. E. H. Krieg

64. W. C. Kuykendall

65. J. R. Lawson

66. J. M. Loar

67. L. W. Long

68. F. C. Maienschein

69. R. B. McLean

70-74. L. E. McNeese

75. J. R. Merriman

76. L. J. Mezga

77-78. M. E. Mitchell

79. B. L. Morgan

80. O. B. Morgan, Jr.

81. J. B. Murphy

82. F. R. Mynatt

83. T. E. Myrick

84. C. E. Nix

85. G. W. Oliphant

86. D. C. Parzyck

87. B. D. Patton

88. F. S. Patton, Jr.

89. C. Pepper

90. T. P. Perry

91. W. E. Porter

92. H. Postma

93. M. L. Poutsma

94. R. E. Pudelek

95. C. R. Richmond

96. A. L. Rivera 


\author{
97. G. D. Robbins \\ 98. J. G. Rogers \\ 99. P. S. Rohwer \\ 100. M. W. Rosenthal \\ 101. T. H. Row \\ 102-103. T. F. Scanlan \\ 104. J. E. Shoemaker, Jr. \\ 105. W. D. Shults \\ 106. R. Shultz \\ 107. L R. Simmons \\ 108. J. H. Smith \\ 109. M. E Smith \\ 110. C. L. Stair \\ 111. J. 0. Stiegler \\ 112. L. H. Stinton \\ 11 3-138. L. E Stration \\ 139. J. H. Swanks \\ !40. T. O. Tallant \\ 141. G. E. Testerman \\ 142. W. T. Thompson \\ 143. W. W. Thompson \\ 144. J. R. Trabalka \\ 145. H. E. Trammell
}

146. C. S. Traiaglini

147. M. D. Trundle

148. D. R. Underwood

149. C. K. Valentine

150. S. D. Van Hoesen

151. V. C. A. Vaughn

152. L. D. Voorhees

153. R. L. Wendt

154. S. K. Whatley

155. G. E. Whitesides

156. M. K. Wilkinson

157. L. C. Williams

158. R. S. Wiltshire

159. J. M. Wolfe

160. R. G. Wymer

161. E. L. Youngblood

162. A. Zucker

163-164. Central Research Library

165. Document Reference Section

166-167. Energy Information Library

168. Laboratory Records-RC

169-170. Laboratory Records Department

171. ORNL Patent Section

\section{EXTERNAL DISTRIBUTION}

172. W. D. Adams, Room 2116, Department of Energy, Oak Ridge Operations, P.O. Box E, Oak Ridge, TN 37831

173. T. W. Clarkson, Ph.D., School of Medicine, Box RB\&B, University of Rochester. Rochester, NY 14642

174. A'. B. Crummett, Ph.D., Dow Chemical, U.S.A., Analytical Laboratory, 574 Building, Midland, MI 48640

175. J. E. Dieckhoner, DP-14, Room B-207, 19901 Germantown Road, Germantown, MD 20874

176. C. A. Dunbar, Roane State Community College, Harriman, TN 37748

177. R. L. Egli, Room 3025, Department of Energy, Oak Ridge Operations, P.O. Box E, Oak Ridge, TN 37831

178. J. Farley, ER-65, Room 340, 19901 Germantown Road, Germantown, MD 20874

179. W. A. Frankhauser, DP-122, Room A-230, 19901 Germantown Road, Germantown, MD 20874

180. J. A. Garrett, 101 Windham Road, Oak Ridge. TN 37830

181 183. G. Gibbs, EH-I, Forrestal Building, 1000 Independence Avenue, S.W., Washington, D.C. 20585

184 185. H. W. Hibbits, Room G-1/4, Department of Energy, Oak Ridge Operations, P.O. Box E, Oak Ridge, TN 37831 
186. P. S. Highberger, Chem Nuclear Systems Inc., 220 Stone Ridge Dr., Columbia, SC 29210

187. ü. M. Hornberger, Ph.D., Department of Environmental Science, Clark Hall, University of Virginia, Charlottesville, VA 22903

188. J. C. Jennett. Ph.D., Dean, College of Engineering, Clemson University, Clemson, SC 29631

189. E. A. Jordan, DP-122, Room A-234, 19901 Germantown Road, Germantown, MD 20874

190. A. G. Joseph. ER-40, Room 7B-040. Forrestal Building, 1000 Independence Avenue, S.W., Washington, D.C. 20585

191. M. R. Jugan, Room 2116, Department of Energy, Oak Ridge Operations, P.O. Box E, Oak Ridge. TN 37831

192-206. R. A. Jump. Room 2116, Department of Energy, Oak Ridge Operations. P.O. Box E, Oak Ridge, TN 37831

207. J. C. Landers, D-5, Room C-460, 19901 Germantown Road, Germantown, MD 20874

208. D. A. Layton, Esq., Buxton, Layton, Webster, \&ilkinson, 800 Oak Ridge Turnpike, Oak Rige, TN 37831

209. J. C. Lehr, DP-124, Room A-214, 1990: Germantown Road, Germantown, MD 20874

210. J. A. Lenhard, Room 3303, Department of Energy, Oak Ridge Operations, P.O. Box E, Oak Ridge, TN 37831

211. W. Nelson Lingle, Room 2116, Department of Energy, Oak Ridge Operations, P.O. Box E, Oak Ridge, TN 37831

212. D. O. Marsh. Ph.D., Department of Neurology, University Medical Center, Box 673, University of Rochester, Rochester, NY 14642

213. The Honorable J. R. McNally, III, 121 Amanda Drive, Oak Ridge, TN 37830

214. C. E. Miller, U.S. Department of Energy Surplus Facilities Management Program Office, P.O. Box 550, Richland, WA 99352

215-216. W. E. Murphie, NE-23, Room D-422, 19901 Germantown Road, Germantown, MD 20874

217. D. Padgett, Chem Nuclear Systems Inc., 220 Stone Ridge Dr., Columbia, SC 29210

218. F. L. Parker, Ph.D., Department of Civil and Environmental Engineering, Vanderbilt University, Nashville, TN 37235

219-220. J. M. Penry, Room 1114, Department of Energy, Oak Ridge Operations, P.O. Box E, Oak Ridge, TN 37831

221. A. B. Selber, Nuclear Assurance Corp., 6251 Crooked Creek Rd., Norcross, GA 30082

222 239. R. C. Sleeman, Room 2116, Department of Energy, Oak Ridge Operations, P.O. Box E, Oak Ridge, TN 37831

240. R. J. Smallridge, Ph.D., Oak Ridge City Schools, P.O. Box 930, Oak Ridge, TN $37831-0930$

241 244. R. J. Willard, Room 2209, Department of Energy, Oak Ridge Operations, P.O. Box E, Oak Ridge, TN 37831

245 246. J. G. Yates, ER-42, Room 3F-091, Forrestal Building, 1000 Independence mvenue, S.W., Washington, D.C. 20585

247. Assistant Manager. Energy Research and Development, Department of Energy. Oak Ridge Operations, P.O. Box E, Mak Ridge, TN 37831

248 250. Technical Information Center, P.O. Box 62, Oak Ridge, TN 378.31 